Pacific Northwest Energy Related

Regional Assessment Program

\title{
The Influence of Selected Federal Statutes on Energy Development
}

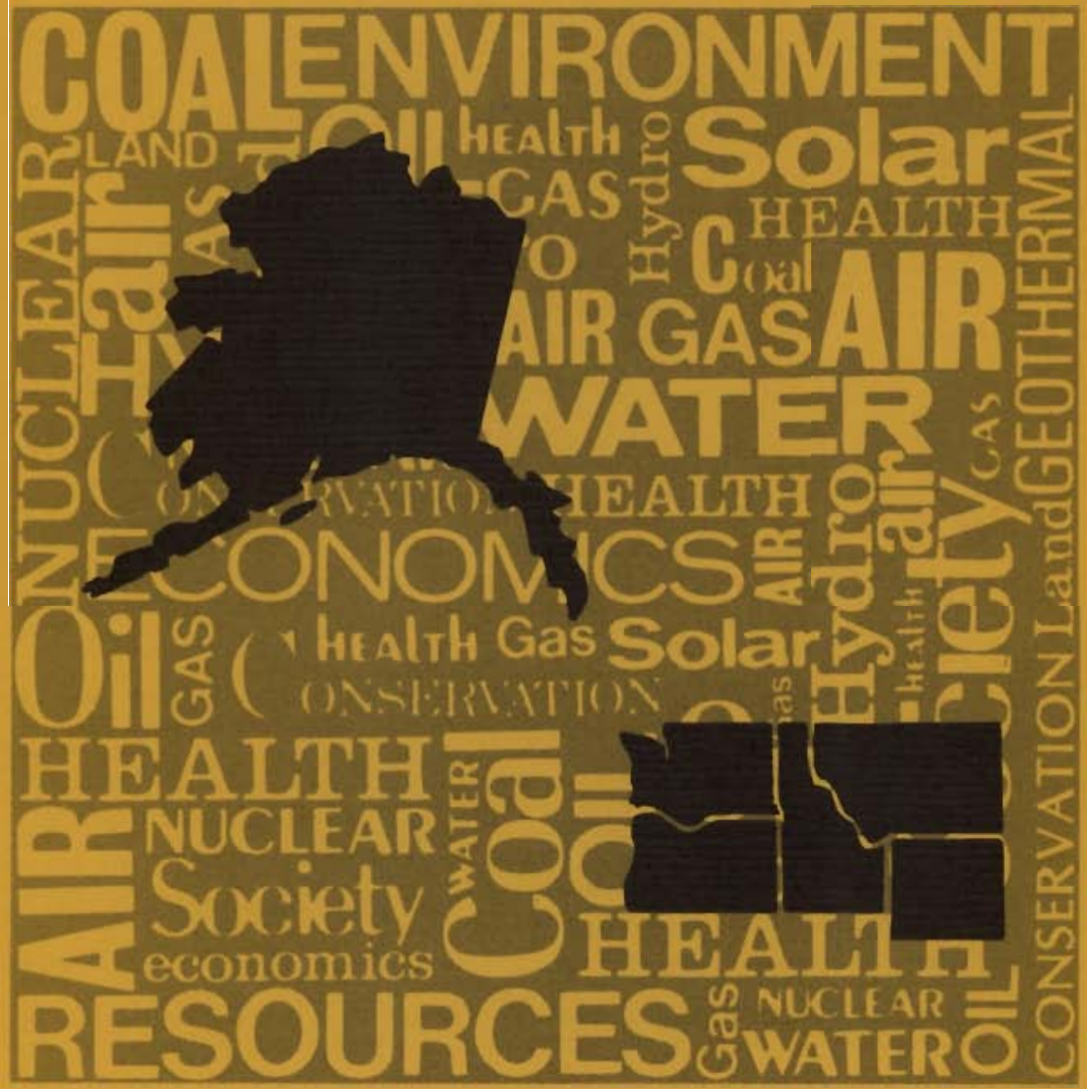

\section{June 1976,}

Prepared for the U.S. Energy

Research and Development Administration under contract AT(45-1):1830

\section{ตัต Battelle}


NOTICE

This report was prepared as an account of work sponsored by the United States Government. Neither the United States nor the Energy Research and Development Administration, nor any of their employees, nor any of their contractors, subcontractors, or their employees, makes any warranty, express or implied, or assumes any legal liability or responsibility for the accuracy, completeness or usefulness of any imformation, apparatus, product or process disclosed, or represents that its use would not infringe privately owned rights.

\title{
PACIFIC NORTHWEST LABORATORY \\ operated by \\ BATTELLE \\ for the
}

ENERGY RESEARCH AND DEVELOPMENT ADMINISTRATION

Under Contract E(45-1)-1830

\author{
Printed in the United States of America \\ Available from \\ National Technical Information Service \\ U.S. Department of Commerce \\ 5285 Port Royal Road \\ Springfield, Virginia 22151 \\ Price: Printed Copy 55.50; Microfiche $\$ 2.25$
}


BNWL-2084

RAP -5

$\mathrm{UC}-11$

\section{3}

THE INFLUENCE OF SELECTED FEDERAL STATUTES ON ENERGY DEVELOPMENT

by

Marty Curry

Marjorie Greene

Battelle Human Affairs Research Centers

June 1976

BATTELLE

Pacific Northwest Laboratories

Richland, Washington 99352 


\section{CONTENTS}

INTRODUCTION •

Overview . . . . . . . . . . . . . . . . . . . . . 1

The Energy Development Process . . . . . . . . . . . 2

Land Requirements . . . . . . • . . . . . 3

Water Requirements . . . . . . . . . . . . 3

Transportation Requirements . . . . . . . . . . . . . . 44

Labor Requirements . . . . . . . . . . . . . . . 4

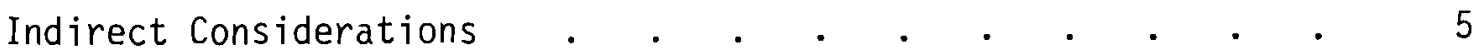

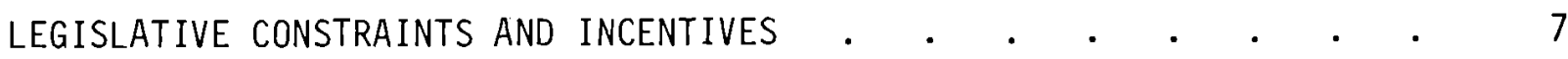

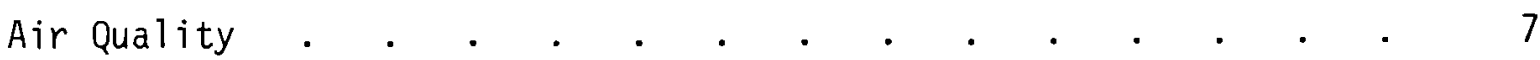

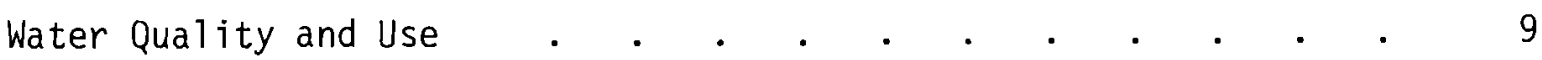

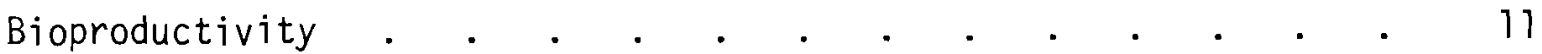

Land Use . . . . . . . . . . . . . . . . . . . 13

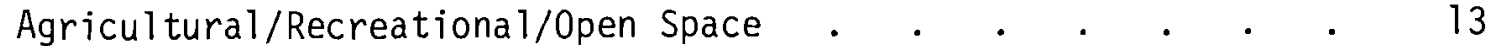

Native Americans . . . . . . . . . . . . . . . 14

Mining . . . . . . . . . . . . . . . . . . 15

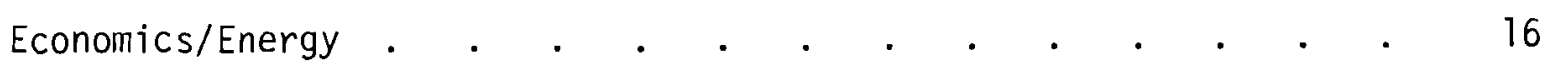

Energy Regulation . . . . . . . . . . . . . . . . . 16

Energy Conservation . . . . . . . . . . . . . . 19

Administration of Energy Policy and Development . . . . . 20

Energy Research and Development . . . . . . . . . 21

Economic Development . . . . . . . . . . . . . 22

Community Development . . . . . . . . . . . . . . . 23

Housing and Public Facilities . . . . . . . . . . 23

Health Care . . . . . . . . . . . . . . . . . 25

Transportation . . . . . . . . . . . . . . . . . 26

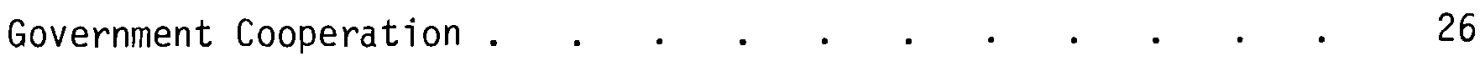

Summary and Conclusion . . . . . . . . . . . . . . . . 27

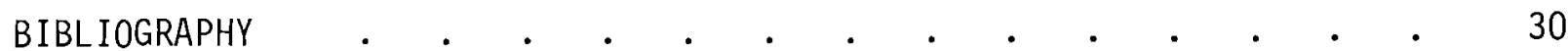

APPENDIX A: Air Quality Statutes . . . . . . . . . . . A.l

APPENDIX B: Water Quality and Use Statutes . . . . . . . . . B.l 


\section{CONTENTS (Contd)}

APPENDIX C: Bioproductivity Statutes . . . . . . . . C.1 APPENDIX D: Land Use Statutes . . . . . . . . . . . . . . 0.1 APPENDIX E: Economics/Energy Statutes . . . . . . . . E.l APPENDIX F: Community Development Statutes . . . . . . . F.l 


\section{INTRODUCTION}

\section{OVERVIEW}

This report outlines and discusses the major Federal statutes which can act as constraints and incentives to the various types of energy resource developments and their resulting impacts. While state and local legislation, and other political and institutional factors may create more immediate constraints and incentives regarding the location of energy developments, Federal legislation can supersede state and local powers and often sets a precedent for similar state legislation. This study, then, a small part of a larger Regional Assessment program which will examine institutional barriers and incentives to energy development and investigate potential management strategies for energy impacts, deals with the first layer of constraints--Federal legislation.

For this discussion, constraints and incentives are the laws and resulting policies and guidelines which limit and/or encourage certain development policies and actions. These laws set parameters along several dimensions within which all development actions must occur. The dimensions, which are the sectors of the Regional Assessment Program are 1) air quality, 2) water quality, 3) bioproductivity, 4) land use, 5) economics/energy, and 6) community development (social/demographic/psychological issues).

This report has been organized along the six dimensions mentioned above. We first describe briefly the characteristics of the Pacific Northwest region and of the energy development/production process. We then provide a general overview of the Federal legislative constraints and incentives, including some discussion of their content and the implications of each piece of legislation for energy resource development. (Appendices $A$ through $F$ contain brief abstracts of each piece of legislation.)

A detailed analysis of the interpretation and operation of these Federal laws has not been possible given the time and resources available, but should definitely be the next step in any complete analysis of the institutional and administrative framework within which energy development occurs. The complete 
analysis should 1) examine the Federal energy planning process and the interface of this process with the very important role of private industry in energy development; and 2) analyze and discuss energy-related legislation and the energy planning process in each state of the region, and analyze impact management strategies and mitigation measures for their relevance and applicability to each states' planning process. In addition, the interface between the private and public sectors at the state level and the role of private industry in identification of techniques to administer energy development and energy management and development of impact management strategies and mitigation measures should be discussed.

\section{THE ENERGY DEVELOPMENT PROCESS}

A general description of the energy production and development process for each type of resource shows how these processes can be regulated and impacted by statutes and institutional constraints and incentives.

Several parts of the various production and development processes appear to have the most significant implications for policy development; land, water, transportation and labor requirements. Several indirect results, such as social changes and changes in the environmental quality, can also affect energy policy. These factors overlap, of course, but they have been identified separately because each is controversial in its own right.

Energy production processes for each of the fuels potentially available in the Pacific Northwest has similar basic steps. Exploration and discovery of the resource is the first step necessary to all development processes. Extraction of the resource is a second step common to most; for hydroelectric facilities, dam construction is the likely equivalent to mining or extraction. This second step may also include reclamation if the extraction process involves disruption to the land. The third step common to the development of most energy sources is some type of processing or refining of the raw material. In some cases a step between extraction and processing is the transport of the raw material to a processing or refining station. Another transport step occurs after refinement, involving the transport of the energy itself. Coal, 
oil shale, crude $0 i 1$ and natural gas are often transported after refinement to a final destination where they are used as fuel. Coal and natural gas, along with nuclear, geothermal and hydroelectric energy, can also be transmitted as electricity from their processing plants.

The following paragraphs briefly identify the major issues for the parts of the energy production process most likely to have implications in policy development.

Land Requirements

Land is utilized both directly and indirectly in most energy production processes. Direct land utilization is generally greatest for fuel extraction and energy transmission, while indirect land usage appears to be greatest for energy production or conversion. The total amount of land used in any energy development process is of course highly dependent on the amount of success of reclamation and restoration. Almost always, competing interests for the use of the land--energy developers, the agricultural sector, and recreation interests in the Northwest region, for example--increase the priority on attempts to conserve, reclaim and restore as much land as possible. For energy technologies involving a mineral resource, the controversy among competing interests is particularly bitter; the mineral rights have been leased separately from the ownership of the surface land, making it likely that a development company wil1 at least temporarily destroy the surface 1 and, which is probably ranch or farming land, in its mining operations.

Energy transmission, such as the transmission of electricity, can also require substantial land acreage. Easements and rights-of-way, including pipeline rights-of-way for $0 i 1$, coal and natural gas, may require land which is in another use if transmission systems are built above the ground.

Land use is affected also by the population growth associated with energy resource development, in the form of added pressures to develop land for residential and commercial uses.

Water Requirements

Almost a11 energy production processes require substantial amounts of water in development and production; this water is in most cases also needed 
by other industries, the agricultural sector and municipalities. Water rights are created and transferred separately from land, as are mineral rights, causing particularly severe problems in the water-short, semiarid states of Montana and Wyoming. There, water may be diverted from major tributaries by energy companies, causing shortages for the users of water farther downstream. The problem is exacerbated by the complicated controversy over water ownership, particularly on Indian lands where much of the mineral development may occur. Coal conversion processes are expected to use large amounts of water; the nuclear industry requires large amounts of cooling water, some of which is lost through evaporation; and hydroelectricity is of course generated by the movement of large quantities of water.

Transportation Requirements

Almost every energy production process has transportation requirements, either transportation of the fuel before refinement or the transportation of the finished fuel product to generating stations, etc. There are also transportation requirements for the materials used in the energy production process. All of the transportation alternatives for the various energy technologies, such as the trans-Alaska pipelines, the shipment of crude oil by tankers, the transportation of coal by unit trains or slurry pipelines, and the overland transportation of radioactive waste, have risks and regulations associated with them.

\section{Labor Requirements}

Manpower is needed to build energy production facilities and related structures such as pipelines and to maintain and operate the production facilities. In the sparsely populated Northwest, these labor requirements usually cause large population influxes to very rural areas, unequipped to deal with the new population. Often, specialized skills are required for the construction and maintenance work, precluding the hiring of many of the local residents. The imported labor force sometimes brings different social values and customs, creating friction between oldtimers and newcomers. Also, the construction force is often much larger than the operation and maintenance force, which means that rural communities are left with large infrastructures and facilities and little revenue after the construction force leaves. 
Indirect Considerations

Each energy technology disrupts the environment to a certain extent. The byproducts of all types of energy production include water and air pollutants and solid wastes. In some cases the removal of these byproducts requires pollution control equipment often equal in size to the energy production facility. In some cases, such as the coal development industry in Montana, Federal and state environmental regulations strictly control the course of development, and play a major role in the determination of the feasibility of the various energy technologies.

Another indirect consideration related to energy development is the social and economic impact of development activities. Such impacts usually include rapid population growth and increased revenues and expenditures for the locally impacted communities including increases in the need for and cost of most public services. These impacts often can be controlled and managed, to varying extents, by Federal and other governmental technical and financial assistance programs. However, if steps are not taken to ameliorate these impacts, they can have more far-reaching and permanent effects than the physical changes caused by the energy development facilities. 


\section{LEGISLATIVE CONSTRAINTS AND INCENTIVES}

The following section briefly discusses the Federal statutes operating as constraints and incentives in each of the impact sectors of the Regional Assessment Program. A detailed analysis of how these laws will directly affect impacts in each specific sector is out of the purview of this study, and will in fact be conducted by specific tasks in each of the sectors. Here, the intention is a general overview of the intent and purpose of these laws. Table 1 is an outline in graphic form of the discussion to follow.

\section{AIR QUALITY}

The Federal government's responsibility to maintain air quality is governed by the Clean Air Act and its 1970 amendments. The Clean Air Act as amended gave the Environmental Protection Agency (EPA) power to establish national ambient air quality standards, standards of performance for new stationary sources and national emission standards for hazardous air pollutants. The Supreme Court later ruled that State Implementation Plans are required for a 11 states to prevent the significant deterioration of present air quality levels. Another court order directed the EPA to promulgate regulations designed to maintain the National Ambient Air Quality Standards after 1975. EPA has standards for these five areas of responsibility, all of which will impact significantly the energy development areas of the Pacific Northwest.

EPA regulations wi1l affect not only direct source emissions (such as $\mathrm{SO}_{2}$ emitted from coal-fired power plants) but indirect source emissions resulting from many of the development activities which occur during urban growth. Some EPA regulations may also affect the location of new energy development facilities. For example, if the new Clean Air Act amendments now before Congress are enacted (which require maintenance of existing air quality for a 60 mile radius from national parks and wilderness areas), it may be difficult for new coal development facilities to locate in the Rocky Mountain states. 


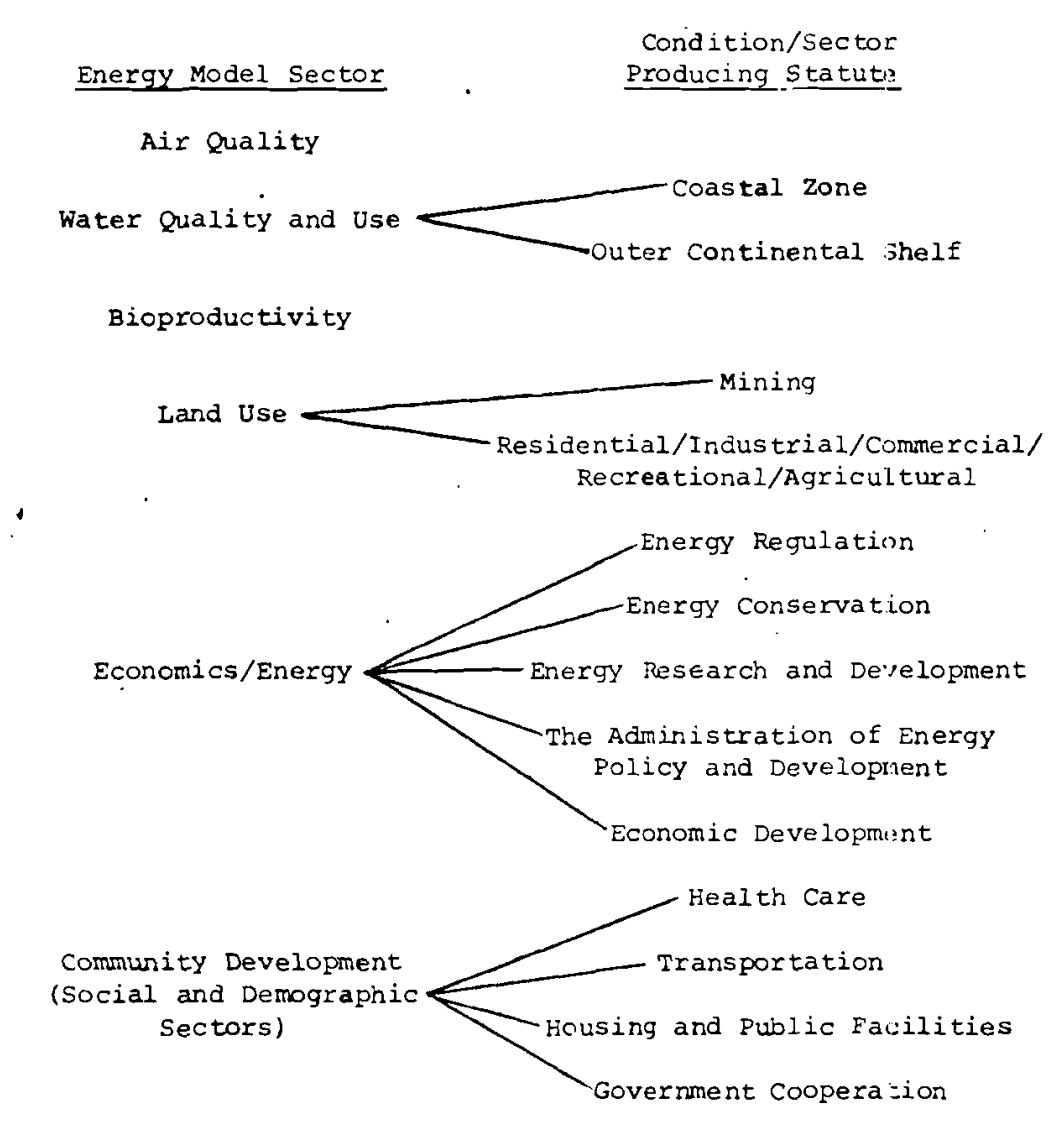

\section{Example of Specific Statute and Its Potential Impact:}

\begin{tabular}{|c|c|c|c|c|}
\hline Condition & Statute & Types of Constri & ints and Incentives & Potertia: $=-\pi=0$ \\
\hline Economics/Energy $\longrightarrow$ Energy Conservation & $\begin{array}{l}\longrightarrow \text { Enersy Policy and } \\
\text { Conservation Act } \\
\text { of } 1975\end{array}$ & $\begin{array}{l}\text { - Regulations } \\
\text { - Financial Assistance } \\
\text { - Tecinical Assistance }\end{array}$ & $\begin{array}{l}\text { Development of } \\
\text { Energy Conservation } \\
\text { Contingency Plans }\end{array}$ & $\begin{array}{l}\text { Federal incettives } 00 \text { stat:a } \\
\quad \text { governments }=0 \text { conserve } \\
\text { energy }\end{array}$ \\
\hline Social/Demographic $\longrightarrow$ Native Americans & $\begin{array}{c}\longrightarrow \text { Alaska Native Claims } \\
\text { Set:tlement Act }\end{array}$ & $\begin{array}{l}\text { - Regulations } \\
\text { - Finarcial Assistance } \\
\text { - Administrative Assistance }\end{array}$ & $\begin{array}{c}\text { Division of Lands } \\
\text { For (Surface Estate) To Native } \\
\text { Regional Corporations }\end{array}$ & 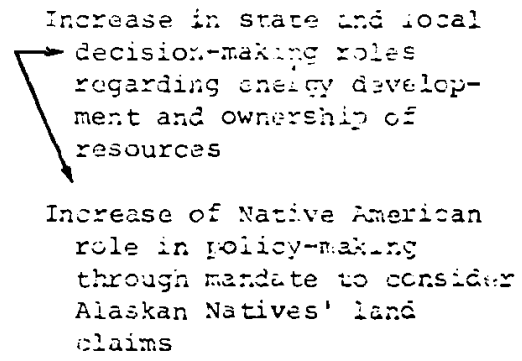 \\
\hline
\end{tabular}


WATER QUALITY AND USE

The quality and uses of the nation's water are regulated by several major Federal laws. Because water availability--for cooling and transport--is critical in energy development, these laws governing water are especially important. Also, in the semiarid states of the Pacific Northwest (Montana and Wyoming) there are problems of water ownership and water rights and conflicting and incompatible demands for water.

In 1965 joint Federal-State River Basin commissions were established, as well as the Water Resources Council--a first recognition of the need for conservation, development and utilization of water-related land resources in a comprehensive and coordinated fashion. The Water Resources Council was given the mandate to continualiy study the adequacy of water supplies needed to meet water requirements in each water resource region.

Another basic law governing water quality is the Federal Water Pollution Control Act (FWPCA) and its amendments. This act provides financial and technical assistance to the states for state and area-wide water quality management planning and implementation programs. The act provides that EPA wi 11 certify eligibility for financial assistance to any state or local public body carrying out waste treatment projects. The act also mandates EPA to conduct research in several areas (including harmful effects of pollutants, practical means of treating municipal sewage, lake pollution, oil pollution control studies, solid waste disposal equipment for vessels, effects of pollution on estuaries and estuarine zones) and develop demonstration programs of the alleviation of some of these water problems.

Another law which provides authority to maintain water quality is Section 13 of the Rivers and Harbors Act of 1899 (also known as the Refuse Act). This act authorizes the Department of Transportation and EPA to prohibit refuse matter from being deposited in navigable waters or on the banks of navigable waters.

Another source of Federal technical assistance for the preservation of water resources is the Water Bank Act. This act authorizes the Department of Agriculture to preserve, restore and improve the wetlands of the nation and 
thereby to conserve surface waters and contribute to improved water quality. One of the main purposes of this act is the promotion of total water management planning.

Financial and technical assistance is also provided to the states under the Safe Drinking Water Act. This act sets up national primary drinking water standards and states are given major responsibility for enforcement.

Generally these pieces of Federal legislation place constraints on energy resource developments, use and effect on waters, through their influence on the type, size, and location of developments that either require large amounts of water or deteriorate the quality of water for other users.

There are also several laws which may affect, most specifically, the transport of oil and natural gas. The Jones Act prohibits any merchandise from being transported between points in the United States except in vessels built in the United States and owned by United States citizens. The Deepwater Port Act of 1974 regulates the location, ownership, construction and operation of deepwater ports in waters beyond the territorial limits of the United States. The Secretary of Transportation is mandated to issue the licenses under this act, and cannot issue a license unless the adjacent coastal state to which the deepwater port is to be directly connected by pipeline "has developed, or is making at the time the application is submitted, reasonable progress toward developing an approved coastal zone management program." The Ports and Waterway Safety Act of 1972 gives the Coast Guard authority over tanker design and operation (additional authority is given to the coast Guard in the FWPCA).

There are also several pieces of legislation which cover resource development and extraction in offshore waters. The Federal government, through the Coastal Zone Management Act of 1972, encourages states to develop and implement plans for managing coastal areas which will preserve and protect these natural resources. While not mandatory, this legislation encourages state management by providing financial assistance and by passing control of Federal activities to states with approved programs. 
A proposed amendment to the Coastal Zone Management Act would somewhat assist energy development in coastal areas by providing funds for coastal energy facility siting and related planning and by providing assistance to impacted states and communities.

The Federal government (Department of Interior) has jurisdiction over mineral resources, including $0 i 1$ and gas off the continental shelf not reserved to states by the Submerged Lands Act. Federal jurisdiction over offshore lands generally begins beyond the three-mile limit, which falls within state jurisdiction (Submerged Lands Act of 1953). Under the Outer Continental Shelf (OCS) Lands Act, the Department of Interior leases land for the development of oil, gas and other minerals, and permits geological and geophysical exploration. In addition the Coast Guard has authority over navigational regulations (0il drilling apparatus).

This OCS act gives the Federal government power over natural resource development beyond state jurisdiction on offshore lands, thus enabling the Federal government to influence the timing and direction of energy exploration and development in these areas. A proposed amendment would impose strict liability for oil spills and set up an offshore 0il Pollution Settlement Fund. This proposed amendment would likely discourage some investments in this type of development but also would encourage other coastal and water-related investments which would be protected by the legislation.

A final area of Federal involvement in water issues is the treaties between Indian tribes and the United States government. These treaties are particularly concerned with water rights, and according to a Supreme court ruling the water on reservations is exempt from appropriation by non-Indians pursuant to state 1 aw; sufficient water must be reserved for present and future needs of Indians, whatever the use and without limit.

\section{BIOPRODUCTIVITY}

In addition to general concern for the environment and community development, the Federal government is also specifically concerned about the protection and preservation of fish and wildlife and their habitats (ecosystems 
or bioproductivity). Federal legislation constrains resource development in areas that have been designated as wildlife refuges or where certain species of fish and wildlife are protected. Eighty-six wilderness areas, established under the Wilderness Act of 1964, are to be administered so as to leave them unimpaired for future use and enjoyment as wilderness. This act authorizes the acquisition of lands designated as wilderness areas. Such lands may be exploited for resource exploration and development, but regulations are established for the reclamation of the land after such use; this may preclude certain types or phases of resource development activities.

Federal legislation also establishes wildlife refuges for the protection and conservation of fish and wildlife threatened with extinction, and other game and wildlife ranges, wildlife management areas and waterfowl production areas. Acquisition of 1 and for these purposes is authorized. Again, mining and mineral leasing laws apply to these areas but such activities must not destroy or damage the areas for wildlife or fish. Related legislation addresses specifically the protection of endangered species and migratory birds. The Endangered Species Act of 1973 authorized the acquisition of 1 and for protective purposes, thus possibly eliminating some land for resource development. These laws also authorize financial assistance to state and local governments for the development of programs for the conservation of endangered species. The Land and Water Conservation Fund Act authorizes Federal assistance to states in planning, acquisition and development of land and water areas for outdoor recreation uses.

Federal legislation regarding preservation of wilderness habitats and wildlife is not limited to financial assistance. The Fish and Wildlife Coordination Act of 1974 very directly places constraints on resource development by requiring that wildlife conservation receive equal consideration and be coordinated with other features of water resource development programs. This policy assures that water resource development projects (which include energy resource water uses) will not harm wildlife conservation efforts and encourages intergovernmental coordination to this end. 
LAND USE

Agricultural/Recreational/0pen Space

Although there is no comprehensive land use legislation at the Federal level, a number of laws relating to specific aspects of land use place some limitations upon the use of land for resource development and production. Generally, Federal land use legislation focuses on public lands and on the management and preservation of areas of public use and interest.

Many acts establish constraints which are intended to protect natural resources and maintain a balance between natural and man-made land uses. Several of these laws are particularly relevant to the western states and their resource development potential.

The concepts of multiple use and sustained yield dominate the administration of national forests (Muttiple Use and Sustained Vield Act of 1970 and Classification and Multiple Use Act of 1964). Under these 1aws, the Forest Service and the Bureau of Land Management are to develop criteria for determining the disposal or retention of specific Federally owned 1ands. They also are authorized to take actions which assure that public lands held even temporarily are administered so as to promote the multiple use and sustained yield concepts. This authority, however, may be preempted by the President (under the Pickett Act), who may withdraw public lands temporarily from settlement, location, or sale for several purposes, including setting up resource reserves or for irrigation. These lands would still be open to mineral exploration and purchase, so they would not create a major constraint to potential resource development. While these acts do not directly constrain the development of mineral resources, their focus on Federal management of surface resources may indirectly limit mineral development by protecting or promoting the several renewable surface resources that would be affected by many resource development processes (e.g., forests).

Federal concern for maintaining renewable resources also is evidenced by the Forest and Rangeland Renewable Resources Act of 1974 which provides assistance for developing long range plans and programs for the nation's renewable resources. Under this act the Department of Agriculture is authorized to 
conduct periodic surveys and assessments of the renewable resources and the impact of programs on the multiple use and sustained yield concepts which govern the administration of national forests and other public lands. Finally, this legislation calls for the provision of an adequate transportation system within the national forests, a condition which tends to make such areas more accessible to resource development.

Another law affecting national forest and park lands is the National Trails System Act. This act authorizes the establishment of trails within urban areas and more remote scenic areas, designating the Appalachian Trail and Pacific Crest Trail as initial components. It mandates that efforts be made to avoid activities incompatible with the purpose for which such trails were established. This Federal commitment to provide a system of recreational trails may constrain the location of resource developments in certain areas, particularly in the western mountain states.

The authority of the Department of Interior to designate unused public lands as grazing districts (Taylor Grazing Act of 1934), while intended to promote the highest use of such lands pending their final disposal, may discourage unrestricted resource exploration and development in these areas. Where individuals are utilizing public lands for grazing purposes, there may be pressures to maintain that use and not open up the lands for other uses. These potentially competing demands would be resolved by the Department of Interior; the need to resolve such conflicts would limit the ease with which resource developers could enter some areas for exploration and development.

The Open Space Act imposes an indirect constraint on land use impacts resulting from energy development activities. The growth generated by energy developments would put pressure on surrounding urban or local areas to accommodate an influx of population and thus increase pressure for urban development of any undeveloped lands that might be planned as urban open space under this act.

\section{Native Americans}

In addition to general Federal laws affecting land use, the Alaska Native Claims Settlement Act significantly influences the development of resources in 
that state. Under this act, Alaskan native groups and villages are to select, within the state, lands for their use, except for 80 million acres set aside by the Department of Interior for public lands. While current mining claims in lands selected will be held valid for 5 years, the right to explore, develop, and remove minerals from the surface estate of native lands is subject to approval of the Native Village Corporation. However, the regional corporations hold jurisdiction over the subsurface estate rights and can lease those mineral rights separately from the land. This Federal act, which supersedes state laws, is an important constraint to resource development in Alaska since it turns authority for approving such development over to the native corporations.

Mining

The enormous coal deposits located in several regions of Montana and Wyoming and the potential massive coal developments in Alaska have generated widespread interest in the types of regulations governing coal development. The type of coal mining used in the Rocky Mountain region is surface or strip mining. Reclamation is also an important issue, but presently no Federal legislation governs reclamation. Several pieces of legislation, however, impose regulations and requirements on mining, and as a result will have a major impact on coal mining and development.

Basically there are two types of mineral claims--locatable and leasable minerals. The Mining Law of 1872 uses the location-patent system (primarily uranium is now mined under this system) and the Mineral Leasing Act of 1920 uses a system of prospecting permits and mineral leases. The mineral leasing acts require that leased lands be developed within a certain number of years. However, these requirements have not been enforced until recently. The Multiple Mineral Development Act of 1954 provides an answer to conflicts that can arise when an area is valuable for mineral leasing under the 1920 Act and for minerals locatable under the 1872 Act. Its basic principle is that each activity must be conducted "so far as reasonably practicable" to avoid damage to minerals subject to the other. 
There is much controversy over mineral rights on Indian land, a particularly important issue in this region because of large amounts of coal on the Crow and Northern Cheyenne reservations in Montana. The Tribal Leasing Act authorizes leasing Indian mineral rights to private corporations under certain conditions; many leases were granted under this act which are now contested by the Indians of the reservations who maintain they had no voice in the original leasing decisions. Court decisions are being awaited in some cases where the Indians have rescinded leases to private developers originally granted by the Bureau of Indian Affairs.

\section{ECONOMICS/ENERGY}

\section{Energy Regulation}

Several major Federal laws regulate different aspects of energy development activities. (See also the discussion under Administration of Energy Policy and Development and the discussion under Mining of Legislation which regulates coal leasing activities). The National Environmental Policy Act (NEPA) mandates that any Federal activity which creates a "significant" change in the environment must be preceded by an environmental impact statement outlining all effects of the project, including socioeconomic impacts and alternatives to the proposed actions. Thus this legislation regulates rather severely the initial planning and development stages of energy facilities by insuring that careful consideration will be made of possible alternatives and all possible consequences of the development.

The Trans-Alaska Pipeline Authorization Act regulates the construction and operation of the oil pipeline in Alaska. This act decrees that the pipeline is to be built without further compliance with NEPA and without further delay (environmental regulations had been responsible for several years delay in the construction starting date). This act sets up a Liability Fund for vessels loading $0 i 1$ at terminals and also decrees that holders of the rightof-way are liable for control and total removal of any pollutant that damages or threatens to damage the environment. This act both encourages energy 
development by removing all obstacles to pipeline construction, and also constrains energy development activity by imposing costs of pollutant clean-ups on the responsible parties.

The Natural Gas Pipeline Safety Act of 1968 also establishes constraints (or safety standards) which must be complied with by the builders of both natural gas and onshore oil pipelines. It is possible under this act to obtain waivers from meeting the safety standards, and if the establishment of a standard affects continuity of gas services, the Federal Power Commission and the state commissions must be consulted and both activity and the effective date of the standards deferred until they have an opportunity to grant appropriate authorization.

The transmission of electric power and the sale and transport of natural gas are also regulated by specific laws. The Bonneville Power Act and the Federal Columbia River Transmission Act regulate the electric power transmission network from the Federal dams to the major load centers in the Pacific Northwest. The Bonneville Power Administration (BPA) markets the power generated at the Federal dams on the Columbia River, and under the authorization of this act the BPA administrator can provide electric transmission lines and substations, and can acquire land necessary for easements, rights-of-way, transmission lines and substations.

The Federal Power Act and Natural Gas Act are both administered by the Federal Power Commission (FPC). The Federal Power Act created the Federal Power Commission and provides guidelines for the licensing system which the FPC is to use in licensing water power sites (hydroelectric facilities). The licensee is to cooperate fully with the FPC by providing required information and the FPC is to decide on the fair value of power from government dams. Under the Natural Gas Act the FPC has the authority to regulate the wellhead price of natural gas and to license onshore natural gas pipelines in interstate commerce.

The oil industry is regulated in its exploration and development by mining and water use (OCS Lands Act) legislation, and in pricing it has been regulated by the United States tax laws. 
The geothermal industry is regulated by the Geothermal Steam Act of 1970 which set up regulations for leasing known geothermal resource areas. The act regulates the amount of land any one person or corporation may lease at one time, and prohibits leases from being granted in national recreation areas, wildlife refuges, and lands which are reserved for the protection and conservation of fish and wildlife threatened with extinction.

The geothermal and solar industries are also affected by research and development legislation which provides incentives for demonstration programs and further research. (See section on Energy Research and Development.)

The nuclear industry is regulated by the Nuclear Regulatory Commission, established under the Energy Reorganization Act. This commission sets standards and safeguards for the industry, and regulates its further development. (See section on Administration of Energy Policy and Development.)

Other environmental legislation imposes indirect regulations on the energy development process. In general, these regulations affect the types of processes used in exploration, extraction, production and the transport of the energy resource by regulating their impacts on different aspects of the environment. (Each are discussed under the appropriate sector in this report.) For example the mining laws, some of the land use laws, some Federal laws related to water, (such as the Outer Continential Shelf Act and the Coastal Zone Management Act) and some recent research and development legislation (related to solar and geothermal power) affect exploration, extraction and production of a specific energy resource. Transport of the energy resource is affected by legislation related to water, (such as the Deepwater Port Act and the Ports and Waterway Safety Act) and legislation related to land use (see water and land use discussions).

Two important areas which have not been covered in this discussion are tax regulations and statutes regulating the railroads. The Internal Revenue Code imposes many important exemptions and benefits for the various types of energy developments; the railroad laws regulate the transport of materials and energy products by rail, and the interstate commerce laws regulate the transport of these materials and energy from one state to another. However, 
because the issues surrounding tax and railroad statutes are very complex it was decided not to include them in this general overview. More time and a more detailed analysis should be devoted to these complicated statutes; followon work for this project may begin such an analysis.

\section{Energy Conservation}

The relatively recent awareness that energy resources are being depleted has caused great public interest (although not much involvement) in energy conservation. Although the emphasis to date has been on the development of new sources of energy rather than the conservation of existing sources, one major Federal act directly structures and encourages attempts at energy conservation. This act, the Energy Policy and Conservation Act of 1975, administered by the Federal Energy Administration (FEA), focuses largely on conservation. It authorizes FEA to set up various programs to encourage, stimulate and direct energy conservation. FEA is charged with administering a major program of technical and financial assistance to states to assist them in setting up their own energy conservation plans.

Another agency with direct conservation responsibilities (and it should be noted here that the continued existence of the FEA has not been decided) is the Energy Research and Development Administration (ERDA). ERDA's conservation programs include: electric energy systems; energy storage; industry conservation; building conservation; transportation conservation; and improved conversion efficiency.

The passage of this act and the devleopment of conservation programs indicate the new emphasis the Federal government is placing on energy conservation. Conservation increasingly is being offered as an alternative to the development of a polluting or undesirable energy source; Federal policy encouraging conservation will increase the likelihood that conservation can be a viable alternative. The impact of conservation on the development of other energy sources is still unclear, but it is possible that the alternative of conservation will decrease the chances of the country accepting massive increases in energy-related activities with many associated undesirable consequences. 


\section{Administration of Energy Policy and Development}

No Federal energy policy provides the direction or overall framework for the administration of energy resources and energy development. There is, however, major Federal legislation which impacts energy resource administration and development in specific areas.

The National Environmental Policy Act (NEPA) is the cornerstone of most environmental legislation at all governmental levels and has significant implications for energy development because it requires comprehensive environmental impact statements and adherance to their findings. The impact identification and description process has added monetary and time costs to the development of most energy projects.

Three major Federal agencies are concerned with the overall management and direction of energy development; they were established in 1974. The Energy Research and Development Administration (ERDA) and the Nuclear Regulatory Comnission (NRC) were created as separate agencies to delineate more clearly the promotional and regulatory functions of the disbanded Atomic Energy Commission. NRC has become the regulatory body for the nuclear industry and ERDA has broad overseeing powers for resea'rch and development of various sources of energy (see section on Energy Research and Development). The third Federal agency established in 1974 is the Federal Energy Administration (FEA), which was created as a result of the oil embargo in 1974 (first as the Federal Energy Office; legislation later established the FEA). The primary functions of this administration are the development of measures to overcome energy shortages, to conserve scarce energy supplies and to insure fair and efficient distribution of energy supplies.

Another law tangentially related to the administration or overseeing of energy development is the Technology Assessment Act of 1972. This act established an Office of Technology Assessment (OTA) as an advisory body to Congress. This office has not been operating for several years, but is now expected to resume functioning. The OTA is to advise congress of the consequences of technological solutions to existing and emerging national problems, and may 
come to play a more important role in assessing effects of new energy technologies on society, thus influencing the direction of Federal energy policy.

The legislation identified in this section provides technical assistance (FEA assistance, for example, to states and local governments), regulations for energy development (such as NEPA requirements for environmental impact statements) and coordinates the development of a Federal energy policy. A law which directly impacts the administration or coordination of energy development in this country is the Energy Policy and Conservation Act of 1975. This act emphasizes conservation, regulation of certain energy uses if necessary, and the development of coal resources over petroleum and natural gas products. It is administered by the Federal Energy Administration. (See section on Energy Conservation.)

Energy Research and Development

The major Federal statutes which impose constraints on energy development provide financial and technical assistance for research, development and demonstration; they focus on non-nuclear as well as nuclear sources of energy. Federal responsibility for energy development is very large, particularly by providing financial assistance and subsidies to the solar and geothermal industries (which are not yet financially viable and able to compete in the free-enterprise system). Thus, it becomes important to understand the commitments the Federal government has made to all energy sources.

The changing energy situation in the early 1970's precipitated a reorganization of the energy promotion, regulation and research structure of the Federal government to reflect a broader research and development approach. One new agency to emerge from the reorganization was the Energy Research and Development Administration, representing the promotional half of the disbanded Atomic Energy Commission, with additional scope. The reorganization authorized ERDA to continue to direct Federal activities in nuclear research and development. In addition, several pieces of recent Federal legislation mandate ERDA to encourage research and development in non-traditional energy sources. These acts give ERDA (in the case of solar energy, HUD and NASA also have administrative responsibilities) authority to direct research programs in 
solar, geothermal and other non-nuclear energy technologies and to develop demonstration programs for these technologies. A Solar Energy Research Institute is established (the location and administration of the Institute now being decided) and ERDA is called upon specifically to set up solar heating and cooling demonstration programs for residential and commercial buildings. These new acts authorize ERDA to provide financial aid for development and demonstration of energy alternatives, which now are not commercially viable, including financial incentives to individuals to use these nontraditional energy sources in their homes.

The Non-Nuclear Research and Development Act of 1974 requires that the Water Resources Council assess water resource needs and water supply availability for non-nuclear technologies and assess the need and availability of water as a precondition for Federal assistance. This is a further example that water is becoming one of the most important criteria in energy development decisions.

\section{Economic Development}

The country's economic development is governed by a vast collection of Federal and state laws. Presented here is some of the more recent legislation which may have some effect on how communities cope with growth associated with energy development.

The State and Local Fiscal Assistance Act of 1972, which instituted general revenue sharing, is presently the major source of Federal financial assistance for local communities. The monies can be used for capital expenditures, which, in energy development areas could include expenditures associated with rapid community growth. However because of increasing costs and shrinking financial resources most communities have used their revenue sharing monies to date for operating expenses of ongoing programs. Because revenue sharing dollars are distributed by a formula which accounts for population, income and tax effort, rapidly growing energy development communities in rural areas may receive increasing proportions of their state's and county's allocations in the future. 
Federal financial assistance for community public works and facilities and economic development and adjustment programs to help states and local areas cope with problems resulting from severe changes in economic conditions are also provided by Federal legislation. Such financial and technical assistance can be used to particular advantage by rural communities facing population influxes, a changing economic and employment base and increased demand in public services. The existence of Federal financial and technical assistance programs can affect the magnitude of social and economic impacts resulting from energy development and, as such, should be carefully noted by energy and government officials.

\section{COMMUNITY DEVELOPMENT}

\section{Housing and Public Facilities}

Communities adjacent to resource developments may feel an indirect but often substantial impact of development activities, primarily in the rapid influx of population and the resulting pressures on community services. Several general Federal statutes seek to improve local governmental capabilities to meet such needs. Foremost among these are Section 701 of the Housing Act of 1954 and the Housing and Community Development Act of 1974. The 701 Comprehensive Planning Assistance Program provides financial assistance to governmental bodies engaged in long-range planning, and grants and assistance to areas with special needs. Such financial assistance helps communities to assess and plan for area needs and assures that recipients meet certain requirements such as land use, housing, citizen participation and environmental components in their planning.

The Housing and Community Development Act of 1974 is the major Federal community development program for local communities; it focuses heavily on meeting housing needs of low income persons. Another section deals specifically with assistance for rural housing research which could help in rural resource development areas. While this legislation should improve the capabilities of local governments to deal with growth pressures related to energy resource development, it may also place some constraints on the community 
impacts that are allowable by such development activities. For example, assistance which improves code enforcement and conservation of land might limit the availability of land and housing for incoming population, although at the same time it would help to improve the quality of housing and urban life for those already residing in the community. Similarly, the Noise Control Act and Amendments (1972) and the Clean Air Act and Amendments place constraints on unharnessed development and growth, but do so in order to retain acceptable levels of air and noise quality in communities. Both of these acts establish standards and enforcement procedures and provide financial assistance for related research. (See sections on Air and Water Quality.)

While the Federal government has not set standards regarding solid waste disposal levels and methods, the Solid Waste Disposal Act authorizes EPA to encourage and finance research, demonstrations, etc., relating to solid waste management technology (especially resource recovery) and to provide financial/ technical assistance to enhance intergovernmental cooperation and planning. The Emergency Community Facilities Act of 1970 provides grants to local entities for basic public water and sewer facilities (including acquisition of land for future facilities) in communities which show need for assistance in providing these services. Such localities must meet requirements of developing plans and projects which will serve foreseeable needs and are coordinated with areawide planning.

A section of the Rural Development Act of 1972 authorizing rural industrial assistance could provide Federal incentives and aid for economic aspects of energy resource development in rural areas. Under this act, the Department of Agriculture is authorized to provide loans to public, private or cooperative organizations and Indian tribes to finance business, industry or employment and to improve the economic and environmental climate in rural communities. Such aid could assist in developing other economic opportunities in areas impacted by energy resource developments, particularly in providing needed services and in taking up any slack in a boom-bust cycle caused by fluctuating resource development employment demands.

In genera1, the Federal legislation related to community development encourages planning and coordination at the state and local levels that will 
assure equitable distribution of services and facilities while maintaining a high quality of life in urban and rural communities. It thus helps to ensure local capabilities to manage growth-related impacts of resource development, in such a way as to prevent deterioration of community life that might occur without adequate planning. In some cases this may discourage more growth than can be handled within any one community or region, thus indirectly 1 imiting the location and distribution of resource developments.

Health Care

Federal legislation related to health care acts only as a tangential constraint to energy resource development. The discussion here focuses on legislation designed to provide assistance to communities in health planning and in the provision of health personnel, facilities and programs. The existence of such Federal assistance (financial and technical) would help communities impacted by resource development-related growth to cope with increasing and changing health care needs.

Four laws provide grants, loans, etc., for such purposes. The Federal Comprehensive Health Planning Amendments of 1966 provide educational training grants, state grants for areawide health planning, and comprehensive health services. The Partnership for Health Amendments of 1967 provide grants and contracts for health research, experiments, and related training to states, and loans or grants for construction projects. This act also authorizes the Public Health Services to serve seamen, Federal employees and certain other persons (e.g., Native Americans). The Health Resources Development Act provides assistance and loan guarantees for medical facilities, modernization or construction projects. This act focuses particularly on areas with need (rural, urban poverty areas) such as some of those likely to be impacted by energy resource development projects. Finally, the National Health Planning and Resources Act of 1974 promotes a national health planning policy and provides assistance toward the development of adequate areawide and state planning and provision for health services manpower and facilities. It includes the development of standards, guidelines and priorities, and estab1 ishes Health Services Areas. These organizational policies help to assure 
that areas with sudden growth and resulting increased hea th care needs will be assisted in maintaining adequate health standards and services through state planning and resource systems.

Transportation

Adequate transportation is a crucial consideration in the location decision of energy resource developments. The movement of extracted and processed resources and of workers to and from the worksites must be assured in order to increase the economic feasibility of the development. Affected communities also must deal with increased traffic flows caused by increased population. Two Federal laws help to assure that these needs will be met. The Federal Aid Highway Act provides financial assistance to states and localities for acquisition of 1 and and construction of primary, urban, secondary and interstate highways. The overal1 purpose of this act is to promote the construction of Federal highways systems adequate to meet the needs of local and interstate commerce. Special emphasis is placed on improvement of highways to provide development of economic growth centers and facilitate mobility of labor in sparsely populated areas (e.g., rural areas).

The National Mass Transportation Act of 1974 promotes the development of mass transit systems, particularly in urban areas, which embrace various modes of transportation to serve local and state needs. This legislation would affect resource development decisions only in the case of urbanized areas being impacted by the influx of population.

\section{Government Cooperation}

In a governmental structure and organization as complex as that of the United States the Federal government uses several techniques to increase and encourage intergovernmental cooperation. The A-95 review process, established by the Intergovernmental Cooperation Act of 1968 is one such technique; it provides for state, regional, metropolitan, and local governmental input into early stages of Federal project planning. This input is made to assure consistency and compatibility between Fedẹral projects and state, regional and local development plans and programs. This process has obvious implications 
for Federal energy development projects and for resource development projects on Federa 1 lands by allowing the state and local area a voice in any final project decision. That is, each state and local agency is asked to comment on how a Federal program will impact their plans and programs. Federal agencies are required to plan to insure consistency and compatibility with state and local programs.

The Joint Funding Simplification Act is also a mechanism for streamlining intergovernmental action. The act consolidates the administration of grants from several Federal agencies through one Federal fudning source. As energy development projects become increasingly important in the Northwest, and as communities and states receive aid from more than one Federal agency, the provisions of this act will streamline Federal aid to states and local communities.

\section{SUMMARY AND CONCLUSION}

This brief overview of the many Federal statutes which may influence energy development highlights several basic concepts regarding the Federal role in the development process.

First, Federal legislation influencing energy projects and resulting impacts encompasses many substantive areas, including not only direct Federal regulation and administration of energy research and development but also regulation of environmental impacts, and the provision of several assistance programs for community development. This range of statutes can potentially control and regulate energy development and can help shape energy policy. In addition statutes which set priorities for the research and development of various energy alternatives will influence the future direction of this country's energy program. Ultimately the interpretation and operation of the statutes will determine the shape of future energy policy, and hopefully future research can examine these interpretations.

Second, Federal ownership and control of land and resource rights in the western states is significant. As the major landowner in these resource-rich 
states, the Federal government is the primary actor in formulating and carrying out regulations which determine the direction and extent of energy development in this region. The Federal government is not only able to promulgate regulations and legislation regarding Federal goals in resource development but also can assure that the interpretation and implementation of such regulations are consistent with legislative intent.

The Federal government's power to regulate leasing and development of the oil and natural gas resources beneath the Outer Continental Shelf makes it a major controller of the development of these resources. Land and mineral ownership in the western states and control of the Outer Continental Shelf, plus Federal control over the licensing of nuclear power plants, contribute to the Federal government's ability to assure that Federal policy with regard to the direction and magnitude of resource development will be carried out.

Federal environmental regulations and standards are a third major factor which affect energy resource development in the western states. These regulations are imposed on all Federal projects and projects on Federal lands, thus affecting most of the coal, oil shale, natural gas and oil developments in the west. Interpretation of these statutes, particularly for the maintenance of air and water quality levels; will be crucial in the final administration of the law and should be followed closely by energy planners, decision-makers and developers.

A final factor emerging from this overview of Federal statutes is the existence of legislation to encourage economic and community development in rural areas, and the lack of specific legislation providing impact assistance monies for impacted communities in energy development areas. Economic assistance for some declining and disadvantaged areas, and community development assistance for most localities are provided in several statutes. However a major controversy in decisions regarding energy development in the west is whether existing Federal assistance is sufficient to help small communities cope with energy-related impacts. A proposed amendment to the Coastal Zone Management Act would provide direct financial assistance (in the form of loans) for the mitigation of community impacis;. If passed, this amendment may signify a wider scope of involvement for the Federal government in energy development. 
A multitude of Federal statutes can affect and influence the shape and direction of energy development. This report has attempted to provide a general introduction to these major areas of legislation and to demonstrate the need for understanding the wide range of issues which the Federal government legislates, and which in turn can shape future energy development and energy policy. 


\section{BIBLIOGRAPHY}

Argonne National Laboratory. Social Costs for Alternate Means of Electrical Power Generation for 1980 and 1990, National Technical Information Service, March 1973.

Atmospheric Aspects Work Group. Northern Great Plains Resource Program, Atmospheric Aspects Work Group Report, December 1974.

Beckman, Norman, et al. "National Urban Growth Policy: 1974 Congressional and Executive Action," Journal of the American Institute of Planners, Vol. 41, No. 4, July 1975, pp. 234-249.

Bleiker, Hans. "Community Planning for Coal and 0il Shale Development or A Strategy for Boom-Town Planning," Submitted for Presentation at American Institute of Planners Conference, 1974.

Brewer, William A. "State Energy Policies for the Northwest," Washington Publ ic Policy Notes, Vol. 3, No. 3, July 1975.

Brown, Elizabeth A. E. "Applying NEPA to Joint Federal and Non-Federal Projects,": Environmental Affairs, Vol. 4, Winter 1975, pp. 135-155.

Butcher, Walter and George Hinman. Guidelines for a Northwest Energy Policy: Phase II. Analys is of Energy Policies for 1980, Environmenta7 Research Center, Washington State University, April 1974.

Committee on Merchant Marine and Fisheries. A Compilation of Federal Laws Relating to Conservation and Development of Our Nation's Fish and Wildlife Resources, Environmental Quality, and Oceanography, U.S. Government Printing Office, January 1975.

Corrigan, Richard and Arthur Magida, "The West Readies Itself for the 20th Century Boom or Bust," National Journal, May 15, 1976, No. 20, pp. 666-670.

"Crow Indian Tribes Sue to Void Coal Contracts Let by U.S. in Montana," Wall Street Journal, September 24, 1975, p. 20.

Dolgin, Erica and Thomas G. P. Guilbert (eds.) Federal Environmental Law. West Publishing Co., 1974.

Economic Priorities Report. Leased and Lost: A Study of Public and Indian Coal Leasing in the West, Council on Economic Priorities, Vol. 5, No. 2, 1974.

Energy Research and Development Administration. National Program for Solar Heating and Cooling, Division of Solar Energy, October 1975. 
Environmental Quality Counci1. "Energy," Second Annual Report, Billings, Montana, October 1973.

"Exxon, She 11 Suspend Coal-Mine Projects Until Environmental Study Suit is Settled," Hall Street Journal, September 24, 1975, p. 10.

Federal Energy Administration. Hydroelectric Generating Facilities Report, September 1974.

Gilmore, John S. and Mary K. Duff. "A Growth Management Case Study: Sweetwater County, Wyoming," University of Denver Research Institute, December 1974.

Hassett, Charles M. (ed.) Environmental Law, The Institute of Continuing Legal Education, 1971.

Hemphi11, Gracie and Sue Hickey. "Seattle Public Meeting Briefing Book, December 2-3, 1975," Office of the Assistant Administrator for Planning and Analysis, Energy Research and Development Administration.

Henning, Daniel H. Environmental Policy and Administration, American Elsevier Publishing Co., Inc., 1974.

Kneese, Allen V. and Charles L. Schultze. Pollution, Prices and Public Policy, The Brookings Institute, 1975.

Magida, Arthur J. and Richard Corrigan, "Trying to Pull the Plug on Uncle Sam's Energy Plans," National Journal, May 8, 1976, No. 19, pp. 618-625.

Mancke, Richard B. The Failure of U.S. Energy Policy, Columbia University Press, 1974.

Massoni, Albert L. (director) Planners Rollcall, American Institute of Planners, September 2, 1975.

Massoni, Albert L. (director) Planners Rollcall, American Institute of Planners, December $31,1975$.

Massoni, Albert L. (director) Planners Rollcall, American Institute of Planners, February 27, $19 \overline{76 .}$

Member Tribes in the Native American Natural Resources Development Federation of the Northern Great Plains. Declaration of Indian Rights to the Natural Resources in the Northern Great Plains States, Northern Great Plains Resources Program, June 1974.

Miller, L. Charles, Jr. "Federal Coal Policy: A Current Assessment," Battelle Human Affairs Research Centers Research Report, December 31, 1974. 
MITRE. Proceedings of Legal and Institutional Problems of Electrical Facility Siting Workshop, Sponsored by Office of Energy R \& D Policy, National Science Foundation, June 1975.

Northern Great Plains Resources Program. Effects of Coal Development in the Northern Great Plains: A Review of Major Issues and Consequences at Different Rates of Development, April 1975.

Office of the Federal Register, National Archives and Records Service and General Services Administration. The United States Government Manual 1975/1976, U.S. Government Printing Office, 1975.

The Planning Support Group, Bureau of Indian Affairs and the Tribes of the Northern Plains. Anticipated Socio-Economic Impacts of Coal Development on Indians of the Northern Great Plains. Northern Great Plains Resources Programs, October 1974.

Power Planning Committee. Review of Power Planning in the Pacific Northwest CY 74, Pacific Northwest River Basins Commission, 1975.

Public Land Law Review Commission. One Third of the Nation's Land, U.S. Government Printing office, June 1970.

Rose, Jerome (ed.) Lega 1 Foundations of Environmental Plarining, Center for Urban Policy Research, 1974.

Rosenthal, Albert J. "The Federal Power to Protect the Environment: Available Devices to Compel or Induce Desired Conduct," Southern California Law Review, Vo1. 45, Spring 1972, pp. 397-449.

Ruckelshaus, William D. "The Citizen and the Environmental Regulatory Process," Indiana Law Journal, Vol. 47, Summer 1972, No. 4, pp. 636-644.

Sayvetz, Ann. Energy-Related Legislation in the Rocky Mountain States, Rocky Mountain Center on the Environment, 1974.

The Science and Public Policy Program, University of Oklahoma. Energy Alternatives: A Comparative Analysis, U.S. Government Printing Office, May 1975.

Socio-Economic and Cultural Aspects Work Group. "Discussion Draft," Northern Great Plains Resources Program, June 1974.

Swift, Ward H. "Responsiveness of ERDA RD\&D to the Future Needs of Electrical Utilities," Battelle Pacific Northwest Laboratories, November 12, 1975.

Swift, Ward H. "Energy Resources Development in the Pacific Northwest, Some Potential Effects and an Approach to Analysis," Battelle Pacific Northwest Laboratories. 
Ulton, Albert E. and Daniel H. Henning (eds.). Environmental Policy: Concepts and International Implications, Praeger Publishers, 1973.

U.S. Dept. of Agriculture. A Summary of the Program and Assessment for the Nation's Renewable Resources, Forest Service, August 1975.

U.S. Dept. of the Interior. "Draft Environmental Statement - BPA Participation in Regional Interutility Cooperation," April 1, 1975.

University of Denver Research Institute. The Social, Economic and Land Use Impacts of a Fort Union Coal Processing Complex, NTIS, U.S. Dept. of Commerce, May 1975.

White, Michael D. "Energy Development in the West: A Clash of Federal, State and Local Land Use Planning and Control," Submitted for Presentation at the American Institute of Planners Annual Conference, October 1975.

Zimmerman, Rae. "Energy Resource Management, Environmental Impacts and the Competition for Land," Submitted for Presentation at American Institute of Planners Conference, October 1974. 
APPENDIX A

AIR QUALITY STATUTES 
APPENDIX A

\section{AIR QUALITY STATUTES}

Title of Act: Clean Air Act and 1970 Amendments to Clean Air Act, 42 USC 1857 et. seq. (1970).

\section{Agency: Environmental Protection Agency}

Purpose: To " dequately" protect the public's health from the effects of air pollution and to achieve national ambient air quality standards.

Scope: This act declares that the EPA is responsible for government air quality control for government activities; it encourages cooperative activities; it helps fund grants for air pollution control projects; it declares that the EPA can designate air quality control regions for the attainment and maintenance of ambient air quality but the states have primary responsibility for assuring air quality.

EPA has authorization to set primary and secondary emission standards for certain hazardous air pollutants, emission standards for new stationary sources, and to approve state implementation plans or develop such plans in the face of state inaction. The states are given 9 months to submit a plan-by May 31, 1975, states must meet primary standards for ambient air quality.

The revised regulations stipulate the granting of variances for attainment of statutory emission standards under the state implementation plans; however, the variances are only temporary. The state plans require full public participation and detailed demonstration by the state planning agency that national standards will be met and maintained. 


\section{APPENDIX B}

WATER QUALITY AND USE STATUTES 


\section{APPENDIX B}

\section{WATER QUALITY AND USE STATUTES}

Title of Act: Water Resources Planning Act 1965, 42 USC 1962 (1970).

\section{Agency: Water Resources Counci1}

Purpose: To encourage conservation, development and utilization of waterrelated land resources on a comprehensive and coordinated bas is by the Federal government, states, localities, and private enterprises with the cooperation of all affected Federal agencies, states, local governments, individuals, corporation, business enterprises and others concerned.

Scope: This act provides the legal basis and organizational arrangements the joint River Basin Planning Commission - for states to participate with Federal agencies in water resource planning in each step from assessment of needs to multi-project design and analysis. It establishes the Water Resources Council which shall maintain a continuing study of the adequacy of supplies of water necessary to meet water requirements in each water resource region in the United States and to maintain a continuing study of the relation of regional or river basin plans and programs to the requirements of larger regions of the country.

Title of Act: Federal Water Pollution Control Act and Amendments, 33 USC 1251 et. seq. (Supp. 1973).

\section{Agency: EPA/Transportation}

Purpose: To attain and maintain acceptable water quality through preventing and mitigating water pollution problems.

Scope: EPA monitors and allocates funds to states for state and areawide water quality management planning and implementation requirements of Section 208. The states allocate among areas; more detailed plans and programs are required for areas with complex problems. Plans must be approved by the Regional Administration; all discharge permits and construction grants must comply with the plan. This act also requires state planning, including public participation during plan development, review, and adoption, intergovernmental input, coordination, and integration of water qual ity management planning for state and area planning areas with other agencies and regulatory programs for implementation. This act provides for state development of water quality standards, state anti-degradation policies, review and certification of plans and 5-year plans for states' strategies for water pollution prevention and control. 
An amendment to this act renders owners and operators of vessels which discharge oil into navigable waters, upon the adjoining shoreline, or into waters of the contiguous zone liable for civil penalties and for Federal costs of removal. Section 311 renders owners and operators of onshore and some offshore pipelines liable to penalties and/or removal cost for $0 i 1$ spills into United States navigable waters or the contiguous zone. Responsibility for administration of this section was delegated by EPA to the Department of Transportation.

Title of Act: Refuse Act (Section 13 of the Rivers and Harbors Act of 1899), 33 USC 407 (1970).

\section{Agency: Transportation/EPA}

Purpose: To prohibit refuse matter from being deposited in navigable waters or on the banks of navigable waters.

Scope: This act states that the Secretary' of Transportation shall implement a permit program to regulate the discharge of pollutants and other refuse matter into the navigable waters of the United States or their tributaries and shall prohibit the placing of such refuse matter on their banks. The Secretary shall be responsible for granting, denying, conditioning, revoking or suspending Refuse Act permits. In so doing he shall accept the findings, determinations and interpretations which the EPA administrator shall make respecting applicable water quality standards. A permit shall be denied where the certification prescribed by Section 21 (b) of the Federal Water Pollution Control Act has been denied, or where issuance would be inconsistent with any finding of the EPA administration pertaining to applicable water quality standards and considerations. The Secretary shall also consider other factors, including the effects of the discharge on fish and wildlife.

Title of Act: Water Bank Act, 16 USC 1301-1311 (1970).

\section{Agency: Agriculture}

Purpose: To preserve, restore and improve the wetlands of the nation, and thereby to conserve surface waters, to preserve and improve the habitat for migratory waterfowl and other wildlife resources, to reduce runoff, soil and wind erosion, and contribute to flood control, to contribute to improved water quality and reduce stream sedimentation, to contribute to improved subsurface moisture, to reduce acres of new lands coming into production and to retire lands now in agricultural production, to enhance the natural beauty of the landscape, and to promote comprehensive and total water management planning.

Scope: The Secretary can enter into agreements with land owners and operators in the improvement of migratory waterfowl neting and breeding areas for conservation of water on specified farms, ranches or other wetlands. Such farms, ranches or wetlands are to be identified in a conservation plan developed in cooperation with the soil and water conservation districts. 
The Secretary shall provide adequate safeguards to protect the interests of tenants and sharecroppers, through individual provisions for sharing, on a fair and equitable basis, in payments or compensation under this program.

The Secretary will pay owners or operators of specified wetlands not to drain land, and not to use it for agricultural purposes.

Title of Act: Safe Drinking water Act, 21 USC 349, 42 USC 201, $300 f$ to $300 j-\overline{9}$ (Supp. IV 1974).

Agency: EPA

Purpose: To protect the safety of drinking water supplies throughout the nation, not just those supplies on interstate carriers, and to protect spread of communicable diseases.

Scope: EPA is required to prescribe national primary drinking water standards, designed to protect health to the maximum extent feasible. The provisions of this legislation apply uniform standards for drinking water for a11 urban and rural areas. States are given primary responsibility for enforcement. State authority to adopt and enforce laws or regulations respecting drinking water or public water systems is unaffected - provisions are specified for variances and exemptions. Emergency powers and actions are authorized by EPA against imminent and substantial endangerment to health (EPA can issue orders or commence civil action). Provisions are made for grants for state programs including public water system supervision programs, underground water source protection programs and special study and demonstration project grants. This act establishes the National Drinking Water Advisory Council to advise, consult with, and make recommendations to EPA on matters relating to the activities, function, policies of agencies concerning this Act.

Title of Act: Jones Act, 16 USC 883 (1970)

Agency: Secretary of Commerce, Department of Commerce/Secretary of the Treasury, Treasury Department

Purpose: To regulate the ownership and construction of vessels transporting merchandise between points in the United States.

Scope: This act states that no merchandise can be transported between points in the United States in any vessel except those (including tankers) built in and documented under the laws of the United States and owned by persons who are citizens of the United States.

Title of Act: Deepwater Port Act of 1974, 33 USC 1501-1524; 43 USC 1333 (Supp. IV 1974).

Agency: Transportation 
Purpose: 1) To authorize and regulate the location, ownership, construction, and operation of deepwater ports in waters beyond the territorial limits of the United States. 2) To provide for the protection of the marine and coastal environment to prevent or minimize any adverse impacts which might occur as a consequence of the development of such ports. 3) To protect the interests of the United States and those of adjacent coastal states in the location, construction, operation of deepwater ports. 4) To protect the rights and responsibilities of states and communities to regulate growth, determine land use, and otherwise protect the environment in accordance with law.

Scope: The Secretary of Transportation has the authority to license for the ownership, construction and operation of a deepwater port. When an application has been made to build a deepwater port facility the Secretary must examine and compare the economic, social and environmental effects of the construction, expansion, deepening and operation of a deep draft channel and harbor port. The Secretary can also waive requirements for the removal of all components of a deepwater port if the removal has to do with any components utilized in the transportation of oil, natural gas, or other minerals. The Secretary can designate as an "adjacent coastal state" any coastal state which would be (a) directly connected by pipeline to a deepwater port as proposed in an application, or (b) located within 15 miles of any such proposed deepwater port, if he determines there is a risk of damage to the coastal environment of such a coastal state equal to or greater than the risk posed to a state directly connected by pipeline to the proposed deepwater port.

The Secretary shall not issue a license without the approval of the governor of each adjacent coastal state. The Secretary shall not issue a license unless the adjacent coastal state to which the deepwater port will be directly connected by pipeline has developed, or is making reasonable progress toward developing an approved coastal zone management program pursuant to the Coastal Zone Management Act of 1972 for the area to be directly and primarily impacted by land and water development in the coastal zone resulting from such deepwater port when the application is submitted. 0il discharge, from a deepwater port from a vessel within any safety zone, or from a vessel which has received oil from another vessel at a deepwater port is prohibited. A Deepwater Port Liability Fund is established to help pay for $0 i 1$ removal - a fee of $2 \notin /$ barrel for $0 i 1$ is assessed except for oil transported through the Trans-Alaska pipeline.

Title of Act: Coastal Zone Management Act of 1972, 16 USC 1451-64 (Supp Tement 1973).

\section{Agency: Department of Commerce (delegated to NOAA)}

Purpose: To preserve, protect, develop and where possible, to restore or enhance, the resources of the nation's coastal zone for this and succeeding generations, and to assist states to exercise effectively their responsibilities in the coastal zone to achieve wise use of the land and water resources (that is, to broaden the focus of coastal zone decision making so as to incorporate a state-wide view). 
Scope: This act authorizes the Secretary of Commerce to make annual grants to coastal states for the purpose of assisting in the development of a management program for the land and water resources of the state. (The legislation neither requires state participation nor defines the coastal zone in a given state.) Pursuant to these grants, the Federal government contributes $2 / 3$ of the cost of developing a management program which conforms to the requirements of the act. States may receive grants for up to 3 years while developing these management programs. Once a program has been developed which has been approved by the Secretary of Commerce, the state shall be eligible for continuing administrative grants. States also gain control over Federal activities within their coastal zone by securing management program approval, as the act provides that Federal agencies shall conduct activities and undertake projects in a manner which is "to the maximum extent practicable, consistent with approved state management programs." A proposed amendment to the act would authorize a Coastal Energy Facilities Impact Fund to disburse up to $\$ 250$ million annually for 3 years. Funds would be available for coastal siting and to help coastal zone planning relating to energy facility siting and to help coastal states and communities cope with impacts directly related to OCS development.

Title of Act: Submerged Lands Act of 1953, 43 USC 1301-15 (1970).

Agency: Secretary of Interior.

Purpose: To delineate state and Federal rights and responsibilities in the development of offshore lands, particularly in the mineral exploitation of such lands.

Scope: This act prescribes the distance for which states have jurisdiction over $0 i 1$ and gas production on state lands onshore and offshore. This distance is 9 miles from the coasts of Texas and Florida; 3 miles from the coasts of most other states. The United States retains all its rights and powers of regulation and control of the above lands for the constitutional purposes of commerce, navigation, national defense and international affairs. States gain right to 1) title and ownership of lands beneath navigable waters within the boundaries of the respective states and the natural resources within such lands and waters; 2) the right and power to manage, administer, lease, develop and use the said lands and natural resources all in accordance with applicable state law subject to provisions in this act. $1973)$.

Title of Act: Outer Continental Shelf Lands Act. 33 USC 1321/Supplement

\section{Guard) \\ Agency: Department of Interior (U.S.G.S.) and Transportation (Coast}

Purpose: To confer upon the Federal government jurisdiction over mineral resources, including $0 i l$ and gas, of the continental shelf not reserved to states by the Submerged Lands Act. 
Scope: The Department of Interior leases OCS lands for the development of oil and gas, sulfur and other mineral resources, and permits geological and geophysical exploration. The Geological Survey is responsible for inspecting a 11 OCS operations to insure compliance with laws and regulations. The Coast Guard has authority to promulgate navigation regulations aimed at preventing marine accidents; the authority presently is exercised primarily with respect to oil drilling platforms and navigational towers. A proposed amendment to the OCS Land Act would establish an offshore 0il Pollution Settlement Fund and would impose strict liability for spills. This act gives the Secretary of Interior unrestricted authority to regulate and conserve the production of mineral resources from OCS. He may, if he chooses, institute a system of production controls for $0 i 1$ which would depart from the system used by adjoining states. The Act specifically authorizes the Secretary to cooperate with the adjacent states in their conservation efforts.

Title of Act: Indian Treaties (26 Tribes-North Great Plains) Separate Treaties Between Tribes and United States Government

Purpose: The United States goverrment entered into separate agreements with Indian tribes to assure the fair treatment of Indian tribes regarding land and water rights, and to define the relationship between the United States and tribes and tribal rights.

Scope: In these treaties, of particular importance to resource and energy development are the "prior and paramount rights" granted to Indian tribes to all the waters to which they are geographically related. This interpretation has been sustained in a United States Supreme Court Case (Winter's Doctrine), Winters versus United States, 207 United States 564 (1908). Waters reserved in this manner are exempt from appropriation by non-Indians pursuant to state law, and sufficient water must be reserved for present and future needs of Indians, whatever the use and without limit. (These rights depend in part on the definition of reservation; usually considered to mean a place which provides a permanent home, and a place to live free from encroachment by nonIndians.)

Title of Act: Ports and Waterway Safety Act of 1972, 33 USC 1221-1227; 46 USC 391a (Supp. IV 1974)

\section{Agency: Transportation}

Purpose: To prevent damage to or destruction or loss of any vessel, bridge or other structure on or in the navigable waters of the United States, or any land structure or shore area immediately adjacent to those waters; and to protect the navigable waters of the resources there in from environmental harm resulting from vessel or structure damage, destruction or loss.

Scope: This act gives the Coast Guard additional authority (other authority is in the Federal Water Pollution Control Act) over tanker design and operation. It authorizes the Secretary of the department in which the 
Coast Guard is operating (currently Transportation) to establish rules concerning the design and operation of marine tankers which enter United States waters to protect the marine environment by preventing catastrophic spills. The Coast Guard also has broad authority to establish vessel traffic controls in congested waters under this act. 1974)

Title of Act: Environmental Financing Act of 1972, 12 USC 24 (Supp. IV

\section{Agency: $E P A$}

Purpose: To assure that inability to borrow necessary funds on reasonable terms does not prevent any state or local public body from carrying out any project for construction of waste treatment works determined eligible for assistance.

Scope: The EPA certifies eligibility for financial assistance. Eligibility criteria include certification of inability to obtain monies elsewhere, eligibility under the Federal Water Pollution Control Act, and guarantee of timely payments. 
APPENDIX C

BIOPRODUCTIVITY STATUTES 
APPENDIX C

BIOPRODUCTIVITY STATUTES

Title of Act: Wilderness Act of 1964, 16 USC 1131 et. seq. (1970).

Agency: Forest Service of the U.S. Department of Agriculture, National Park Service and Bureau of Sports Fisheries and Wildlife, U.S. Department of Interior.

Purpose: To insure that some lands are designated for preservation and protection in their natural condition.

Scope: Eighty-six individual "wilderness areas" were established by Congress to form the National Wilderness Preservation System, comprising 10.5 million acres of land. Wilderness areas are to be administered in such a way as to leave them unimpaired for future use and enjoyment as wilderness.

Until midnight December 31, 1983, the United States mining laws and a 11 laws pertaining to mineral leasing shall, to the same extent as applicable prior to September 3, 1964, extend to those national forest lands designated by this chapter as "wilderness areas"; subject, however, to such reasonable regulations governing ingress and egress as may be prescribed by the Secretary of Agriculture consistent with the use of the land for mineral location and development and exploration, drilling and production, and use of land for transmission lines, water lines, telephone lines, or facilities necessary in exploring, drilling, producing, mining, and processing operations, including where essential the use of mechanized ground or air equipment and restoration as near as practicable of the surface of the land disturbed in performing prospecting, location, and in oil and gas leasing, discovery work, exploration, drilling and production as soon as they have served their purpose.

Title of Act: National Wildlife Refuge System Administration Act of 1966 and Amendments of 1974, 16 USC 668dd-668jj (Supp. IV 1974).

Agency: U.S. Department of Interior.

Purpose: To consolidate the authorities relating to the various areas administered by the Secretary of Interior for the conservation of fish and wildlife, including species that are threatened with extinction; all lands, waters and interests therein administered by the Secretary as wildlife refuges. Areas for the protection and conservation of fish and wildlife that are threatened with extinction, wildlife ranges, game ranges, wildlife management areas, or waterfowl production areas are hereby designated as the National Wildlife Refuge System. 
Scope: The Wildlife Refuge System consists of some 341 national wild1ife refuges and game ranges encompassing about $30.5 \mathrm{million}$ acres, as well as some 95 relatively small fish hatcheries. The United States mining and mineral leasing laws shall continue to apply to any lands within the system to the same extent they apply prior to 0ctober 15, 1966, unless subsequently withdrawn under other authority of law. No acquired lands which are or become a part of the system may be transferred or otherwise disposed of under any provision of the law...unless 1) the Secretary of Interior determines after consultation with the Migratory Bird Conservation Commission that such 1 ands are no longer needed for the purposes for which the system established 2) such lands are transferred or otherwise disposed of for an amount not less than (a) the acquisition costs of such lands, in the case of lands in the system which were purchased by the United States with funds from the Migrating Bird Conservation Fund or (b) the fair market value of such lands (as determined by the Secretary on the date of the transfer or disposal) in case the lands in the system which were donated.

Title of Act: Endangered Species Act of 1973, 7 USC 136; 16 USC 460L-9, 460K-1, 668dd, 715i, 715a, 1362, 1371, 1372, 1402, 1531-1543 (Supp. IV 1974).

\section{Agency: U.S. Department of Interior.}

Purpose: To provide a means whereby the ecosystems upon which endangered species and threatened species depend may be conserved, and to provide a program for the conservation of such endangered species and threatened species. A11 Federal departments and agencies shall seek to conserve endangered species and threatened species and shall utilize their authorities in furthering the purposes of this act.

Scope: The Secretary shal1 by regulation determine whether any species is endangered or threatened. To carry out this program the Secretary shall utilize land acquisition and other authority under the Fish and wildiife Act of 1956, as amended, the Fish and Wildlife Coordination Act, as amended, and the Migratory Bird Conservation Act, as appropriate. The Secretary is also authorized to acquire by purchase, donation or otherwise, lands, waters, or interest therein, and such authority shall be in addition to any other land acquisition authority vested in him.

The Secretary is authorized to provide financial assistance to any state, through its respective state agency, to assist in the development of programs for the conservation of endangered and threatened species.

Title of Act: Land and Water Conservation Fund Act, 16 USC 4601-4 to $4601-11(1970)$.

\section{Agency: U.S. Department of Interior.}

Purpose: To assist in preserving, developing, and assuring accessibility to al1 citizens of the United States of America of present and future generations to such a quality and quantity of outdoor recreation resources as may be 
available and are necessary and desirable for individual active participation in recreation--and to strengthen the health and vitality of citizens.

Scope: This act provides funds for and authorizes Federal assistance to states in planning, acquisition and development of needed land and water areas and facilities and provides funds for Federal acquisition and development of certain lands and other areas. A comprehensive statewide outdoor recreation plan is required in the state before the Secretary will consider financial assistance for acquisition or development of projects. $(1970)$

Title of Act: Fish and Wildlife Coordination Act, 16 USC 661-666 (c)

\section{Agency: U.S. Department of Interior.}

Purpose: To provide that wildlife conservation shall receive equal consideration and be coordinated with other features of water resource development programs through the effectual and harmonious planning, development, maintenance and coordination of wildlife conservation and rehabilitation.

Scope: This act requires the Corps of Engineers, Bureau of Reclamation and Federal Power Commission to consult with the United States Fish and Wild1 ife Service, Department of the Interior, and with the head of the agency exercising administration over the wildlife resources of the particular state wherein the water impoundment, diversion or other control facility is to be constructed, with a view to the conservation of wildlife resources by preventing loss of and damage to such resources as well as providing for the development and improvement thereof in connection with such water resource development. 
APPENDIX D

LAND USE STATUTES 


\section{APPENDIX D}

\section{LAND USE STATUTES}

Title of Act: Multiple Use and Sustained Yield Act of 196016 USC $5 2 8 - 3 \longdiv { 1 } ( 1 9 7 0 .$

\section{Agency: Forest Service/Secretary of Agriculture.}

Purpose: To administer national forests for outdoor recreation, range, timber, watershed and wildlife and fish purposes.

Scope: The Secretary of Agriculture is authorized and directed to develop and administer the renewable surface resources of the national forests for multiple use and sustained yield of the several products and services obtained therefrom.

This act does not specify priorities among the various forest uses. It requires a permittee to be compensated for his range improvements if the permitted land is allocated to another permittee. Regulations under the act also provide that an applicant for disposal of land covered by a permit may be required to compensate the permittee for permanent range improvements.

Nothing in this act shall be construed so as to affect the use or administration of the mineral resources of national forest lands.

Title of Act: Classification and Multiple Use Act of 196443 USC $1411-\overline{7418(1970) \text {. }}$

Agency: Bureau of Land Management/Secretary of Interior.

Purpose: To provide criteria for determining disposal of Federal lands administered by the Bureau of Land Management.

Scope: This act provides similar temporary authority (as provided to the Forest Service under the Multiple Use and Sustained Yield Act) for BLM administered lands. In addition, this act directs the Secretary of Interior to develop criteria to be used in determining which of those public lands should be disposed of and which should be retained in Federal ownership for multiple use and sustained yield management. This act does not specify or provide standards for determining priorities of use or guidelines for resolving conflicts.

Title of Act: Pickett Act, 43 USC 141, 142 (1970).

Agency: The Executive Office of the President of the United States. 
Purpose: To allow the President to pursue the public interest in setting aside public lands for specific public purpose regarding resource development and agriculture.

Scope: This act authorizes the President to temporarily withdraw any public lands of the United States from settlement, location, sale or entry. (Between 1910 and 1921 the President used this authority to set aside four public land petroleum reserves which are now by statute designated as naval petroleum reserves to be administered by the Secretary of the Navy. One is in Wyoming and one in Alaska.) He can then reserve the withdrawn land for waterpower sites, irrigation, classification of lands, or other public purposes to be specified in orders of withdrawal, and such withdrawals or reservations shal1 remain in force until revoked by him or by an act of Congress. A11 lands withdrawn sha11 at al1 times be open to exploration, discovery, occupation, and purchase under the mining laws of the United States.

Title of Act: Forest and Rangeland Renewable Resources Act of 1974, 16 USC 581h, 1601-1610 (Supp. IV 1974).

Agency: U.S. Department of Agriculture.

Purpose: To establish a long-term perspective in planning and undertaking related national renewable resource programs.

Scope: The Secretary of Agriculture is directed to make and keep current a comprehensive survey and analysis of present and prospective conditions of and requirements for renewable resources of forest and rangelands of the United States, and of the supplies of such renewable resources, including a determination of the present and potential productivity of land and of such other facts as may be necessary and useful in the determination of ways and means necessary to balance the demand and supply of these renewable resources, benefits and uses in meeting needs of people of the United States. It is authorized to be appropriated not more than $\$ 20$ million in any fiscal year to carry out the purposes of this act.

The Secretary is instructed to complete a renewable resource program which may include alternatives and should provide detail for the protection, management and development of a national forest system. As part of this program the Secretary of Agriculture shal1 prepare national forest system land and resource management plans. The Secretary can use the assessment, resource surveys and the program to assist states and other organizations in proposing the planning for the protection, use and management of renewable resources on non-Federal 1 and.

The Secretary shall prepare an evaluation report of the program every year for Congress. He shal1 take such action as will assure that the development and administration of renewable resources of the National Forest System are in full accord with the concepts for multiple use and sustained yield of 
products and services as set forth in the Multiple-Use Sustained Yield Act of 1960. The installation of a proper system of transportation to service the National Forest System shall be carried forward in time to meet the anticipated needs on an economical and environmentally sound basis.

One section of the assessment program includes: a discussion of important policy considerations, laws, regulations and other factors expected to influence and affect significantiy the use, ownership and management of forest, range, and other associated 1ands. (Due December 31, 1975.)

As part of the program, the Secretary of Agriculture shall develop, maintain, and as appropriate, revise land and resource management plans for units of the National Forest System; he shall coordinate with the land and resource management planning process of state and local governments and other Federal agencies.

The Congress declares that the installation of a proper system of transportation to service the National Forest System shall be carried forward in time to meet anticipated needs on an economical and environmentally sound basis and the method chosen for financing the construction and maintenance of the transportation system should enhance local, regional and national benefits.

Title of Act: National Trails System Act, 16 USC 1241-1249 (1970).

Agency: U.S. Department of Agriculture/U.S. Department of Interior/ Department of Housing and Urban Development.

Purpose: To provide for the ever-increasing outdoor recreation needs of an expanding population and to promote public assess to, travel within and enjoyment and appreciation of open-air, outdoor areas. Trails should be established 1) primarily near the urban areas of the nation, and 2) within established scenic areas more remotely located.

Scope: This act designates the Appalachian Trail and the Pacific Crest Trail as initial components. The Secretary of the Interior is authorized to investigate the feasibility of making other trails national scenic trails. The Secretary must consult with other Federal agencies, and work in cooperation with interested interstate, state and local government agencies, public and private landowners and land users. The trails designated to be studied include (in the Pacific Northwest region) the Lewis and Clark Trail, the Oregon Trail, the Mormon Trail, and the Gold Rush Trails in Alaska. The Secretary is authorized to make efforts to avoid activities incompatible with the purposes for which such trails were established.

Title of Act: Taylor Grazing Act of 1934, 43 USC 315-315 0-1 (1970). Agency: U.S. Department of Interior. 
Purpose: To promote the highest use of the public lands pending their final disposal. The Secretary of the Interior can establish grazing districts on lands which in his opinion are chiefly valuable for grazing and raising forage crops.

Scope: This act authorizes the Secretary of Interior to create grazing districts out of vacant, unappropriated and unreserved lands, to regulate their occupancy and use, and to preserve land from unnecessary injury (such as overgrazing).

Title of Act: Open Space Land Act, 42 USC 1500-1500d (1970).

Agency: U.S. Department of Interior/Department of Housing and Urban Development.

Purpose: To provide grants to state and local public bodies for the acquisition and development of open space land.

Scope: The Secretary is authorized to make grants to states and local public bodies to help finance 1) the acquisition of, title to, or other interest in, open space land in urban areas and 2) the development of open space or other 1 and in urban areas for open space uses. The amount cannot exceed 50 percent of eligible project cost.

The Secretary may provide the technical assistance to states and local public bodies required to effectively carry out these activities.

The Secretary shall make grants only if he finds that such assistance is needed for carrying out a unified, or officially coordinated program, meeting criteria established by him, for the provision and development of open space land which is a part of, or is consistent with, the comprehensive planned development of the urban area.

To encourage the acquisition of interests in undeveloped or predominantly undeveloped land which, if withheld from commercial, industrial and residential development, would have special significance in helping to shape economic and desirable patterns of urban growth (including growth outside of existing urban areas which is directly related to the development of new communities or the expansion and revitalization of existing communities) the Secretary may make grants to state and local public bodies for the acquisition of such interests in an amount not to exceed 75 percent of the cost of such acquisition.

Title of Act: Alaska Native Claims Settlement Act, 43 USC 1601 et. seq. (Supp. I 1971).

\section{Agency: U.S. Department of Interior.}

Purpose: To accomplish a fair and just settlement of all claims by natives and native groups of Alaska, based on land settlement claims. 
Scope: This act divides Alaska into 12 regions (with a 13th for nonresidents) for settlement of land claims. It abolishes reservations and prior claims and permits native villages to select lands for settlement. The Secretary of Interior may withdraw up to 80 million acres of unreserved public lands from native claims consideration. It establishes the Alaska Native Fund monies which are established in the Treasury, and allocated over a period of years to Alaska native groups and villages, through Regional Corporations set up pursuant to this act. Village Corporations must have a plan for the use of the funds before receiving their share of funds. This act supersedes laws of the State of Alaska. Royalties, rents, and bonuses from mineral leases are paid into the Alaska Native Fund. For patents two percent of the gross value of the mineral produced and removed from lands is reserved for the benefit of Alaska natives. Royalties from oil and gas revenues are also paid into this fund. These payments are limited to a maximum of $\$ 500$ million less total advance payments from the Secretary under the Trans-Alaskan Pipeline Authority Act. Subsequent payments are to be placed in the Treasury. Lands selected by Village Corporations are patented to cover rights over the surface estate only; rights to subsurface estates are held by the Regional Corporations. The right to explore, develop or remove minerals from lands within boundaries of any native village is subject to consent of the Village Corporation. Any person with a valid mining claim or location under general mining laws prior to August 31 , 1971, with recorded notice shall be protected in his possessory rights, if all requirements of general mining laws complied with such rights are protected for a periof of 5 years and may, if all requirements of general mining laws are complied with, proceed to patent.

Title of Act: Mineral Leasing Act of 1920, 30 USC 181-263 (1970).

Agency: Interior.

Purpose: To establish procedures for leasing minerals under a leasing and permit system.

Scope: This act governs the leasing of onshore oil, gas and coal, oil shale, as well as some nonfuel minerals (phosphates, sulfur, potassium, sodium, native asphalt and solid and semisolid bitumen and bituminous rock, such as tar sands) on public domain lands in the United States (including Indian lands). It allows exploitation through a system of prospecting permits and mineral leases. Certain lands are excluded, including lands in national parks, incorporated towns and villages, and naval petroleum and oil shale reserves. The act does not apply to acquired lands. In November of 1973 an amendment was enacted by Congress and signed by the President to give Federal officials discretionary authority to grant pipeline rights of way across Federal lands wider than the 50 feet previously permitted, and issue temporary permits to use additional Federal lands for pipeline construction and maintenance.

Title of Act: Mining Law of 1872 (Mineral Location Law of 1872) 30 USC 22 et. seq. (1970).

Agency: U.S. Department of Interior. 
system. Purpose: To outline procedures for leasing minerals under a locatable

Scope: This law applies to all vacant, unoccupied and unappropriated tracts in the public domain, including national forests, and renders these tracts subject to mining claims by persons who discover valuable minerals in these tracts. It uses the location-patent system which is a dichotomous system separating locatable from leasable minerals. Upon completing his location through procedures governed in part by local law and filing requirements, the locator has the exclusive right and possession of all the surface within his claim. One aspect of this law is that mining patents may continue to be granted in wilderness areas until 1984 and indefinitely in certain units of the National Park System and National Wildlife Refuge System.

Title of Act: Multiple Mineral Development Act of 1954, 30 USC 521 et. seq. (1970).

\section{Agency: Interior.}

Purpose: To provide an answer to conflicts that can arise when an area is valuable for mineral leasing under the 1920 Act and for minerals locatable under the 1872 Act.

Scope: This act provides procedures for validating mining claims located under the mining laws between 1939 and 1954 even though at the time the land had been segregated for leasing. The act establishes procedures for settling conflicts which arise when land is used for both mining law and leasing act purposes. The basic principle is that each activity must be conducted "so far as reasonably practicable" to avoid damage to minerals subject to the other. Where there are existing improvements on the land, operations must be conducted so as not to interfere "materially" with such improvements. Courts are authorized to resolve conflicts by awarding compensation to the injured party.

Title of Act: Acquired Lands Act 1947, 30 USC 351-59 (1970).

Agency: Interior.

Purpose: To authorize the Secretary of Interior to lease acquired lands for the purpose of mineral development.

Scope: This act authorizes the Secretary of Interior to lease acquired lands containing minerals subject to the Mineral Leasing Act and the regulatory scheme in this act parallels that of the Mineral Leasing Act. (Acquired 1ands are lands to which title was not originally vested in the United States but which has been subsequently acquired by the United States by purchase, gift or condemnation.) This act does not affect leasing in tidelands, submerged lands, lands underlying the 3 mile zone or belt, or the continental shelf adjacent or littoral to any part of the land within the jurisdiction of the United States. 
Title of Act: Mining and Minerals Policy Act of 1970, 30 USC 21a (1970).

Agency: Interior.

Purpose: To set forth the general policy under which the Secretary of Interior regulates fuel extraction. The act is to foster and encourage private enterprise in 1) the development of economically sound and stable domestic mining and related (reclamation, etc.) industries; 2) the orderly and economic development of these to help assure satisfaction of industrial, security and environmental needs; 3) research; 4) the study and development of methods for the disposal, control and reclamation of mined land so as to lessen the adverse impact upon the physical environment.

Scope: The act authorizes the Secretary of Interior to make an annual report to Congress on the state of domestic mining, minerals, and mineral reclamation industries, including a statement of the trend in utilization and depletion of these resources, together with such recommendations for legislative programs as may be necessary to implement the policy of this act.

Title of Act: Tribal Leasing Act of 1938, 25 USC 396, 396a (1970).

Agency: U.S. Department of Interior.

Purpose: To establish provisions for leasing tribal lands so as to assure benefit to Indians resulting from resource development of 1 ands.

Scope: The Secretary of Interior sets rules and regulations necessary to carry out the act.

Allotted lands: Allottees may lease land for mining purposes (DOI approves terms of lease). Bonds are required by lessee for leases of allotted or tribal lands. If the owner dies without heirs, DOI can lease the land for mining purposes through public auction. Lands held in trust may be leased by allottee for a maximum of 5 years.

Unallotted 1and: This land may be leased by the tribal council or other authorized spokesmen for Indians, for terms not to exceed 10 years and as long after as minerals are produced in payable quantities; approval of DOI is required. This section does not apply to the Crow reservation in Montana, or ceded lands of the Shoshone reservation in Wyoming (or Osage, Choctaw, and Chicksaw in 0k1ahoma).

This act requires the lessee to pay the entire sum of the original cash bonus if the prospecting permit is extended. It also allows leasing through competitive bidding and through agreements negotiated with the lessee. Such negotiated leases are more flexible and allow the leasing tribe the opportunity to bargain for terms that meet their specific needs. 
APPENDIX E

ECONOMICS/ENERGY STATUTES 


\section{APPENDIX E}

\section{ECONOMICS/ENERGY STATUTES}

Title of Act: National Environmental Policy Act, 42 USC 4321, 4331-4335, $4341-4347(1970)$.

Agency: Environmental Protection Agency.

Purpose: To have a systematic interdisciplinary approach to ensure the integrated use of natural, social sciences and environmental design arts in planning and decision-making which may impact man's environment.

Scope: This act identifies and develops procedures for giving proper consideration to environmental values and amenities in decision making; it requires the Envirormental Impact Statement which is to include adverse environmental effects, alternatives to the proposed actions and a discussion of the relationship between short-term uses and long-term productivity of man's environment; irreversible, irretrievable commitments of resources; and equal attention to primary and secondary effects. This act established the Council of Environmental Quality which is to report to the President every year; the Council of Environmental Quality is located in the Executive Office of the President.

Title of Act: Trans-Alaska Pipeline Authorization Act, 43 USC 1651-1655 (Supp. IV 1974).

\section{Agency: U.S. Department of Interior (and others).}

Purpose: To assure that the construction of the Trans-Alaska Pipeline, as described in its final EIS, proceeds without delay.

Scope: This act directs the Secretary of Interior and other Federal agencies to take all action necessary to accomplish construction of the pipeline without delay. This act provides that these actions be taken without any further steps to comply with NEPA and shall not be subject to judicial review under any law. Holders of the pipeline right-of-way are liable (up to $\$ 50$ million for any one incident) for damages resulting from an accident during activities along or in the vicinity of the pipeline right-of-way. Holders of the right-of-way are also liable for control and total removal of any pollutant that damages or threatens to damage the environment. Strict liability (up to $\$ 100$ million) shall also be imposed on vessels loading oil at terminal facilities. The act establishes a Trans-Alaska Pipeline Liability Fund as a nonprofit corporate entity which shall contain $\$ 100$ million (collected from a fee of $5 \$$ / barrel under the Fund). 
Title of Act: Natural Gas Pipeline Safety Act of 196815 USC 717-717w (1970); 49 USC 1674, 1682, 1684 (1970).

Agency: U.S. Department of Transportation. pipelines.

Purpose: To establish safety standards for natural gas and onshore $0 i 1$

Scope: This act requires that pipelines comply with safety standards promulgated by the Department of Transportation's Office of Pipeline Safety. Onshore oil pipelines also must satisfy OPS safety standards. The Secretary establishes minimum Federal safety standards for the transportation of gas and pipeline facilities. This act also establishes the Technical Pipeline Safety Standards Committee.

Whenever the establishment of a standard, or an action upon an application for waiver under the provision of this act, would affect continuity of any gas services, the Secretary shall consult with and advise the Federal Power Commission or state commission having jurisdiction over the affected pipeline facility before establishing the standard or acting on the waiver application and shall defer the effective date until the Federal Power Commission or any such commission has had reasonable opportunity to grant the authorizations it deemis necessary.

Title of Act: Bonnevi1le Project Act of 1937, 16 USC 832-832L (1970).

Agency: U.S. Department of Interior.

Purpose: By forming the Bonneville Power Administration, to provide the electric power transmission network from the Federal dams to the major load centers in the Pacific Northwest. BPA is also the Federal marketing agency for the power generated at those dams. The act provides that the electric energy generated in the operation of the Bonneville project shall be disposed of by the BPA administrator.

Scope: This is one of the acts which gives the Army Corps of Engineers authority to build and operate dams (other acts are Fort Peck Project Act, Flood Control Act of 1944 and Water Resources Planning Act of 1965). Power produced at ACE projects normally is marketed by agencies in the Department of Interior (this act provides for the Bonneville Power Administration to market in the Northwest) at rates approved by FPC. The administrator is authorized and directed to provide, construct, operate, maintain, and improve such electric transmission lines and substations, and facilities and structures appurtenant thereto, as he finds necessary, desirable or appropriate for the purpose of transmitting electric energy, available for sale, from the Bonneville project to existing and potential markets and for purpose of interchange of electric energy. The administrator is authorized to acquire by purchase, lease, condemnation or donation such real and personal property including lands, easements, rights-of-way; franchises, electric transmission lines, substations and facilities as necessary to carry out the purpose of this act. 
Title of Act: Federal Columbia River Transmission System Act of 1974, 16 USC 838-838K (Supp. IV 1974).

Agency: U.S. Department of the Interior/Bonneville Power Administration.

Purpose: To enable the Secretary of the Interior to carry out policies of $\mathrm{PL}$ 88-552 relating to marketing of electric power from hydroelectric projects in the Pacific Northwest; to carry out policies relating to use of revenues of the Federal Columbia River Power System to provide financial assistance to reclamation projects in the Pacific Northwest; the treaty between the United States and Canada relating to the cooperative development of the resources of the Columbia River Basin, and other applicable law, it is desirable and appropriate that the revenues of the Federal Columbia River Power System and the proceeds of revenue bonds be used to further the operation, maintenance and further construction of the Federal transmission system in the Pacific Northwest.

Scope: This act puts the Bonneville Power Administration on a "pay as you go" basis rather than requesting authorization from Congress and Office of Management and Budget for funds from the Treasury for construction, operation and maintenance each fiscal year. The act authorizes BPA to pay for its transmission, construction, and operation and maintenance expenses, from BPA power revenues and proceeds of bonds sold by it to the Treasury at a rate comparable to similar bonds repayable from its revenues.

Title of Act: Natural Gas Act, 15 USC 717-717w (1970).

Agency: Federal Power Commission.

Purpose: To establish Federal regulation in matters relating to the transportation of natural gas and the sale thereof in interstate and foreign commerce, as necessary in the public's interest.

Scope: Under this act, the Federal Power Commission has authority to regulate the wellhead price of natural gas dedicated to interstate commerce, in order to protect consumers. The act provides that natural gas imports must be licensed by the FPC although it has wavered in its regulation of the price of LNG (1iquified natural gas).

Onshore natural gas pipelines in interstate commerce are required by this act to be licensed by the FPC.

Title of Act: Federal Power Act, 16 USC 1a-825r (1970).

Agency: Federal Power Commission.

Purpose: To establish the Federal Power Commission which regulates the power industry. 
Scope: This act provides that water power site values be developed under a Federal 1icensing system. It created the Federal Power Commission to be authorized and impowered to 1) conduct investigations and collect/record data concerning the utilization of water resources of any region to be developed, the water power industry and its relation to other industries and to interstate or foreign commerce, and concerning the location, capacity, development costs and relation to markets of power sites; and whether the power from government dams can be advantageously used by the United States for its public purposes, and what is a fair value of such power; 2) make statements as to the investment of 1 icenses in projects (1 icensee shall give FPC information. concerning the actual legitimate original cost of construction of such project, addition or betterment, and of the price paid for water rights, rightsof-way, lands or interests in land. The licensee shall grant to FPC free access to such project additions, reports, etc.; 3) cooperate with executive departments; and 4) make public from time to time information secured and to provide for publication of reports and documents.

Title of Act: Geothermal Steam Act of 1970, 30 USC 100 (1971).

Agency: U.S. Department of Interior.

Purpose: To set up regulations for the leasing of known geothermal resource areas and other areas where geothermal resource potential exists.

Scope: The act authorizes the Secretary of the Interior to lease any public, acquired or withdrawn lands administered by the Department of Interior or the Department of Agriculture's Forest Service, and any land conveyed by the United States subject to a reservation of geothermal resources. (Withdrawn lands are public domain and acquired lands which have been withdrawn in some degree from the operation of the public land laws relating to settlement, entry, location and sale.) The lease granted shall encompass not more than 2,500 acres, and no person, corporation, or association shall hold, own, or control at any one time, except as otherwise provided in act, more than 20,480 acres in one state. Leases cannot be granted for lands administered in accordance with 1) the act of August 25, 1916 (39 Stat 535) as amended, 2) for lands within a national recreation area, 3) for lands in a fish hatchery administered by the Secretary, a wildlife refuge, wildlife range, game range, wildlife management area, waterfowl production area, or for lands acquired or reserved for the protection and conservation of fish and wildlife that are threatened with extinction, and 4) for tribally or individually owned Indian trust or restricted lands, within or without the boundaries of Indian reservations. note.

Title of Act: Energy Policy and Conservation Act of 1975, 42 USC 6201

Agency: Federal Energy Administration.

Purpose: To conserve energy supplies through energy conservation programs and, where necessary, regulation of certain energy uses; increase the 
United States' supplies of fossil fuels through price incentives and production requirements; grant specific authority to the President to impose rationing and implementation of energy conservation plans; provide for improved energy efficiency of motor vehicles, major applicances and certain other consumer products; and reduce the demand for petroleum products and natural gas through programs designed to emphasize the nation's abundant coal resources.

Scope: This act has a program to guarantee laons to eligible persons for the prupose of developing new underground coal mines; it prohibits certain lease bidding arrangements on OCS lands where major oil companies have a "significant ownership interest" in the person bidding; it authorizes the development of a strategic Petroleum Reserve Plan; it authroizes a report within 180 days after enactment of act recommending procedures for the exploration, development and production of the Naval Petroleum Reserve \#4, including economic, social and environmental interests of the natives residing there; it authorizes the development of energy conservation contingency plans; it amended the Motor Vehicle Information and Cost Savings Act to require fue 1 economy in automobiles starting in 1978 with $18 \mathrm{mpg}$ and going to $27.5 \mathrm{mpg}$ in 1985; it generally authorizes FEA to foster and promote comprehensive energy conservation programs and practices by establishing guidelines, overall coordination, technical assistance and financial support.

The administrator will give financial assistance and will set an industrial improvement target for the 10 most energy-consumptive industries; the administrator will develop and implement a 10-year plan for energy conservation with respect to buildings owned or leased by an agency of the United States. The act amended the Allocation Act by establishing ceiling prices on first sale of crude oil produced in the United States. The act also sets up a program to establish verification examinations for the Energy Data Base and Energy Information program.

Title of Act: Energy Reorganization Act of 1974, 5 USC 5313-5316; 42 USC 5801, 5811-5820, 5841-5849,5871-5879, 5891 (Supp. IV 1974).

\section{Agency: Executive.}

Purpose: To develop and increase the efficiency and reliability of use of all energy sources to meet the needs of present and future generations, to increase the productivity of the national economy and strengthen its position in regard to international trade, to make the nation self-sufficient in energy, to advance the goals of restoring, protecting and enhancing environmental quality, and to assure public health and safety.

Scope: This act establishes the Energy Research and Development Administration to direct Federal activities relating to research and development on various sources of energy. It separates the licensing and regulatory functions of the Atomic Energy Commission into the Nuclear Regulatory Commission. The act establishes the Energy Resources Council which will insure communication among Federal agencies involved with energy policy and management of energy 
resources, make recommendations to the President for measures to improve implementation of Federal energy policies or the management of energy resources, with particular emphasis upon policies and activities involving two or more Departments or independent agencies.

Title of Act: Federal Energy Administration Act of 1974, 15 USC 761-786 (Supp. I I 1974).

\section{Agency: Federal Energy Administration.}

Purpose: To establish a coordinated and effective approach to overcoming energy shortages, conserving scarce energy supplies, and insuring fair and efficient distribution of energy supplies, Congress created the Federal Energy Administration.

Scope: This act established the FEA as an independent agency in the Executive Branch. It transferred the Office of Petroleum Allocation, the Office of Energy Conservation, the Office of Energy Data and Analysis, and the Office of $0 i 1$ and Gas from the Department of the Interior to FEA. The Federal Energy Office was abolished. Under this act the function of the Administration is to advise regarding the establishment of a comprehensive national energy policy; assess adequacy of energy resources to meet demands; develop effective arrangements for the participation of state and local governments in resolution of energy problems; develop plans and programs for dealing with energy production shortages; promote stability in energy prices; develop and oversee the implementation of equitable voluntary and mandatory energy conservation programs and promote efficiencies in the use of energy resources; develop and recommend policies on import and export of energy policies; and generally assemble and disseminate energy-related information and act as the administering agency for national policy related to energy.

Title of Act: Technology Assessment Act of 1972, 2 USC 471-481; 42 USC 1862 (Supp. IV 1974).

\section{Agency: Congress.}

Purpose: To effectively anticipate, understand and consider the consequences of technological applications in the determination of the effect of public policy on existing and emerging national problems.

Scope: This act created an Office of Technology Assessment in Congress with the basic responsibility of providing Congress with "early indications of the probable beneficial and adverse impacts of the applications of technology including the identification of alternative programs for achieving requisite goals." The office is headed by a director and responsible to a Technology Assessment Board composed of six senators and six representatives. There also is a Technology Assessment Advisory Council. This Council reviews and makes recommendations to the Board on activities of the Office. 
Title of Act: Energy Supply and Environmental Coordination Act of 1974, 42 usC 1857b-1 (Supp. IV 1974).

\section{Agency: Federal Energy Administration.}

Purpose: To assist in meeting the essential needs of United States for fuel in a manner which is consistent with existing national commitments to protect and improve the environment and to provide requirements for reports respecting energy resources.

Scope: This act provides that, among other things, FEA can prohibit any power plant from burning natural gas or petroleum products as its primary energy source if the administrator determines the plant has the capabilities and necessary plant equipment to burn coal. The FEA can require that any power plant early in the planning provess be designed and constructed to be capable of using coal as primary energy source. This act provides that any allocation program developed (under authority of the Emergency Petroleum Allocation Act of 1973) shall include measures to assure that available low sulfur fuel will be distributed on a priority basis.

Title of Act: Geothermal Energy Research Development and Demonstration Act of 1974, 30 USC 1101, 1102, 1121-1126, 1141-1144, 1161, 1164 (Supp. IV 1974).

Agency: Energy Research and Development Adminstration.

Purpose: To denote Federal financial assistance to encourage "the extensive exploration, research and development in geothermal resources which will bring these technologies to the point of commercial application." The Federal government has a responsiblity to encourage and assist private industry in the development of the geothermal resource as one alternative to the currently used scarce energy sources.

Scope: The act establishes a Geothermal Energy Coordination and Management Project which has overall responsibility for the geothermal energy research, development and demonstration program. This includes: 1) the determination and evaluation of the resource base; 2) research and development with respect to explanation, extraction and utilization technologies; 3 ) demonstration of appropriate technologies; and 4) a loan guarantee program to encourage and assist in commercial development.

Title of Act: Solar Heating and Cooling Demonstration Act of 1974, 42 USC 2473,5501-5517 (Supp. IV 1974).

Agency: Energy Research and Development Administration/Housing and Urban Development.

Purpose: To demonstrate the practical use of solar heating technology within three years and to provide for the development and demonstration of the practical use of a combined heating and cooling technology within five years. 
Scope: This act encourages the development and demonstration of solar heating systems for use in residential dwellings by establishing performance criteria, entering into contracts and grants for the development of heating systems for commercial production and residential use and contracts for procurement of heating systems and components, by arranging for the installation of heating systems, and operation during the demonstration period, by instal1ing heating systems in dwellings located on Federal or Federally administered property. This act encourages the development and demonstration of combined solar heating and cooling systems and suitable dwellings, and authorizes ERDA to arrange with Federal agencies for the development and demonstration of solar heating and combined heating and cooling systems for commercial buildings. The act also authorizes ERDA to disseminate information to promote the practical use of solar heating and cooling technologies, and to give benefits for mortgage loans for homes fitted with solar heating in a combined heating and cooling system.

Title of Act: Solar Energy Research, Development and Demonstration Act of 1974, 42 USC 5551-5566 (Supp. IV 1974).

\section{Agency: NASA/HUD/ERDA.}

Purpose: To pursue vigorous research and resource assessment of solar energy as a major source of energy for our national needs, and to provide for the development and demonstration of practicable means to employ solar energy on a commercial scale.

Scope: This act establishes the Solar Energy Coordination and Management Project, and initiate a solar energy resource determination and assessment program, a research and development program. This program is for the purpose of resolving the major technical problems inhibiting commercial utilization of solar energy; it is a program to design and construct, in specific solar energy technologies, facilities or powerplants of sufficielst size to demonstrate the technical and economic feasibility of utilizing various forms of solar energy. The act establishes a Solar Energy Information Data Bank, and supports programs of education in the sciences and enegineering to provide the necessary trained personnel to perform solar energy research, development and demonstration activities. The act also establishes a Solar Energy Research Institute.

Title of Act: Non-Nuclear Energy Research and Development Act of 1974, 42 usc 5901 (Supp. IV 1974).

Agency: U.S. Energy Research and Development Administration.

Purpose: To dedicate the necessary financial resources, to enlist scientific and technological capabilities, and to accord proper priority to developing new non-nuclear energy options to serve national needs, conserve vital resources and protect the environment. 
Scope: This act sets the policy and program to be implemented and administered by ERDA. It establishes a national program of basic and applied research and development of all potentially beneficial energy sources and utilization technologies (a11 non-nuclear options). Energy conservation is a primary consideration, as well as national and social consequences of proposed programs; the emphasis is on renewable resources.

This act directs ERDA to develop a comprehensive reserach and development program; ERDA is also to provide Federal assistance through contracts to joint government-industry corporations for experimentation and demonstration projects. ERDA is to develop guidelines for demonstration projects for new energy technologies. There is to be joint Federal/non-Federal sharing of costs. (CEQ is to analyze the technologies for attention to energy conservation and environmental protection; the environmental consequences of these technologies is to be presented in arnual reports to the President.

The Water Resources Council is directed to assess the water resource needs and water supply availability for non-nuclear technologies and to identify the constraints upon the availability of water imposed by treaty, compact or law. The Council is also to analyze the effects of the development of the energy technology on water quality and to assess the need and availability of water as a precondition for Federal assistance for development of the technology.

Title of Act: State and Local Fiscal Assistance Act of 1972, 31 USC $1221-1228 ; 1241-1243 ; 1261-1263$ (Supp. IV 1974).

\section{Agency: Treasury.}

Purpose: To provide Federal financial assistance to state and local governments.

Scope: This act establishes general revenue sharing - a form of general Federal financial assistance to states, counties and municipalities. Funds received under this act by local governments can be used only for ordinary and necessary maintenance and operating expenses for 1) public safety (including law enforcement, fire protection and building code enforcement); 2) environmental protection (including sewage disposal, sanitation and pollution abatement); 3) public transportation (including transit systems and streets and roads); 4) health; 5) recreation of libraries; 6) social services for the poor or aged; 7) financial administration and ordinary and necessary capital expenditures authorized by law. Funds cannot be used as matching funds by state and local governments. $\$ 30$ billion was allocated between January, 1972, and December, 1976, according to a formula. This act provides the major source of Federal assistance for most communites. Allocations are made to states, then to county areas, and then to county governements and local governments. Separate allocations are made to Indian tribes and Alaskan native villages. State and local governments must report on the planned use and actual use of funds, cannot discriminate in the use of funds.

Congress is now considering extension and revision of this act. 
Title of Act: Economic Adjustment Act of 1974, 42 USC 3132-3246 (Supp. IV 1974).

\section{Agency: Commerce .}

Purpose: To amend the Public Works and Economic Development Act of 1965, extending the authorizations for 2 years and to institute a new title which provides special economic development and adjustment assistance programs to state and local areas. These assistance programs are to help state and local areas meet special needs arising from actual or threatened severe unemployment resulting from economic dislocation, including enemployment arising from actions of the Federal government and from compliance with environmental requirements which remove economic activities from a locality, and economic adjustment problems resulting from severe changes in economic conditions, and to encourage cooperative intergovernmental action to prevent or solve economic adjustment problems.

Scope: The new title authorizes the Secretary to make grants directly to any eligible recipient in an area which has experienced, or may reasonably be foreseen to experience, special needs to meet the expected increase in unemployment or other economic adjustment problems to carry out or develop a plan to use such grants for any of the following: public facilities, public services, business development, planning, unemployment compensation, rent supplements, mortgage payment assistance, research, technical assistance, training, relocation of individuals and other appropriate assistance.

Title of Act: Public Works and Economic Development Act Amendments of 1971,42 USC 3123-3191 (Supp. IV 1974).

\section{Agency: U.S. Department of Commerce.}

Purpose: To provide financial assistance for public works and facilities that will help encourage/promote economic development in an area which suffers from the lack of employment opportunities.

Scope: It authorizes the Secretary to make direct grants to states and political subdivisions or Indian tribes, and to private or public nonprofit organizations involved in redevelopment areas for the acquisition or development of land and improvements for public works, public services, or development facility usage. The act also authorizes the acquisition, construction, rehabilitation, alteration, and improvement of such facilities, including related machinery and equipment, within a redevelopment area. However, the project must be shown to directly or indirectly improve the opportunities for employment for low-income families and for the successful establishment and expansion of commercial and industrial plants or facilities. If the area has undertaken an overall economic development program, and if the project provides immediate useful work to unemployed and underemployed persons, such funds may be authorized. The act also makes supplementary grants to states (within redevelopment areas) and other entities to take advantage of Federal 
grant-in-aid programs, particularly in areas that carnot supply the required matching share. The EPA certification is required for sewer/waste disposa 1 facilities requesting assistance (grants, etc.), and must meet Federal, state, interstate or local water quality standards.

E.11 
APPENDIX $F$

COMMUNITY DEVELOPMENT STATUTES 


\section{APPENDIX $F$}

\section{COMMUNITY DEVELOPMENT STATUTES}

Title of Act: Section 701 of the Housing Act of 1954 (Comprehensive Planning Assistance Amendment of 1975) 40 USC 461 (Supp. IV 1974).

Agency: Housing and Urban Development.

Purpose: To develop and improve the overall (1ocal, regional, and state) governmental capability, to improve public service productivity, and to address special problems in planning for impacts from resource development and for energy conservation.

Scope: This act provides financial assistance to governmental bodies engaged in long range plannint ( $2 / 3$ share); it provides grants for areawide planning and management assistance, and assistance to applicants with special needs - including Interstate Regional Commissions (ERA), and those communities experiencing rapid urbanization due to energy resources development and production. Funds are provided for activities related to developing and carrying out a comprehensive plan as part of the ongoing planning process, and for area needs assessment. The applicant-recipient must meet certain requirements: environmental assessment of project; a historic preservation element; a housing plan element; a land use plan element; an equal opportunity element; citizen participation in the planning process; and a comprehensive plan element.

Title of Act: Housing and Community Development Act of 1974, 12 USC 24-1788; 20 USC 801-807; 31 USC $711 ; 42$ USC 1410-5426; 49 USC 1602 (Supp. IV $1974)$.

Agency: U.S. Department of Housing and Urban Development.

Purpose: To develop viable urban communities, by providing decent housing and a suitable living environment and expanding economic opportunities, principally for persons of low and moderate income, and to further the development of a national urban growth policy.

Scope: Title I: This act provides financial assistance to urban communities on an annual basis for community development projects. These include programs to eliminate and prevent slums, blight, and deterioration; to provide improved community facilities and public improvements, including health, social and similar services; to develop housing assistance plans to provide assistance to remedy housing problems, rehabilitate existing stock, and provide new housing for lower income people; to foster housing and community development activities being undertaken in a coordinated and mutually supportive manner - to encourage interstate cooperation. This act phases out 
categorical grant programs. It allows money to be used to acquire property for building and site restoration, beautification and conservation of land, public works, code enforcement and payments to housing owners - relocation provision of public services, planning activities, administration costs. It encourages "congregate housing" - low income housing - and shared facilities.

Title II: Assisted Housing.

Title III: Mortgage Credit Insurance: This title promotes the use of energy saving techniques through minimum property standards (set by HUD) for new housing subject to mortgages insured under this act.

Title IV: Comprehensive Planning (update of 701, Section 402): This section provides training and fellowship programs and monies for the support of state and local research needed in connection with housing programs and needs, code problems, land use, transportation and similar community development problems.

Title V: Rural Housing: provides research and monies.

Title VI: Mobile Home Construction and Safety Standards.

Title VII: Consumer Home Mortgage Assistance.

Title VIII: Miscellaneous: This title encourages state housing agencies; it advocates expanded roles for local housing authorities, state agencies, and state and local government. Special provisions should be made for the elderly and handicapped, thus encouraging more comprehensive treatment of housing.

This act delegates authority to local applicants for performance of the EIS requirements of NEPA - for the block grant projects. HUD certification of a project is deemed fulfillment of NEPA requirements.

Title of Act: Emergency Community Facilities Act of 1970, 42 USC $3101-3108(1907)$.

Agency: Housing and Urban Development.

Purpose: To assist and encourage communities to meet citizen needs by providing Federal grant assistance, to construct adequate basic water and sewer facilities, to construct neighborhood facilities needed to carry on programs for social services, and to acquire land for future public purposes.

Scope: This act gives Housing and Urban Development (HUD) authority to make grants to local public bodies and agencies for basic public water facilities projects and basic public sewer facilities (approved by EPA) to a maximum of $50 \%$ cost of project (90\% to communities under 10,000 if need is demonstrated). Project requirements are set up; grants are made for basic facilities which serve forseeable needs, and which are coordinated with area wide 
planning. The emphasis is on projects providing employment to unemployed or underemployed persons. Grants can be made for neighborhood facilities (but not to nonprofit organizations unless they have the legal, financial, and technical capability to carry out the work) to a maximum amount of $662 / 3 \%$ of the total cost (75\% in Redevelopment Areas). These grants are subject to the same requirements as basic public water and sewer facilities grants. Grants can be made to states and local public bodies for the acquisition of land to be utilized in the future (within 5 years) for public purposes - but the grant cannot exceed the aggregate amount of reasonable interest charges on loans and financial obligations if the land is diverted to other uses, and it may require repayment of the grant or substitution of land of approximately equal fair market value. Projects can be developed on lands not eligible for other Federal grant or loan programs.

Title of Act: Noise Control Act and (1972) Amendments, 42 USC 4901-4918 (Supp. 1973).

\section{Agency: Environmental Portection Agency.}

Purpose: To establish, implement, and enforce regulations controlling noise emissions for (a) products distributed in commerce, (b) aircraft, and (c) railroad noise, and to improve the noise quality of the environment.

Scope: This act authorizes the Environmental Portection Agency to develop and enforce regulations; state and local officials cannot set regulations "which are not identical to such regulations" of this law, but this does not preclude state or political subdivisions from establishing and enforcing noise controls. It establishes the Low-Noise Emission Product Advisory Commission for the certification of products (related to products used by the Federal government); it coordinates with the programs of other Federal agencies, it conducts and provides financial assistance for research, and the Office of Noise Abatement Control.

Title of Act: Solid Waste Disposal Act, 42 USC 3251-3259 (Supp. IV 1974).

Agency: Environmental Protection Agency.

Purpose: To promote the demonstration, construction, and application of solid waste management and resources recovery systems which preserve the quality of air, water, and land resources; it provides guideleines for solid waste collection, research, technical and financial assistance, and training grants.

Scope: The act authorizes EPA to encourage and finance research, experiments, demonstrations, surveys, etc., relating to solid waste management effects and improved technology, and to collect and disseminate information. EPA is to cooperate with public and private agencies and may make grants and contracts for interstate and local state planning. The agency also is authorized to designate a specific agency to be the sole agency to carry out solid 
waste management study for an area. Finally, grants for construction and demonstration projects are authorized with a 15\% Federal contribution. The powers of this act do not supersede the authorities, responsibilities under other provisions of law (HEW, Interior or other Federal agencies). This act includes the Resource Recovery Act which authorizes funding for resource recovery demonstration projects involving solid wastes.

Title of Act: Rural Development Act of 1972, 7 USC 1006-2668, 42 USC 3122 (Supp. IV 1974).

\section{Agency: U.S. Department of Agriculture.}

Purpose: To help rural communities with industrialization.

Scope: Provisions have been revised under this act for making loans to farmers and ranchers to provide more effective credit services to farmers. In addition there is a provision for rural industrialization assistance. This states that the Secretary may also make and insure loans to public, private or cooperative organizations, to Indian tribes or to individuals for the purpose of improving, developing, or financing a business, industry, and providing employment and improving the economic and environmental climate in rural communities, including pollution abatement and control. The Secretary may also make grants to public bodies for measures designed to facilitate development of private business enterprises, including the development construction or acquisition of land, buildings, plants, equipment, access streets and roads, parking areas, utility extensions, necessary water supply and waste disposal facilities, refinancing, services and fees.

This act creates Rural Development Insurance Funds to be used in discharge of obligations of the Secretary under contracts guaranteeing or insuring rural development loans.

Title of Act: Comprehensive Health Planning and Public Health Services Amendments of 1966, 42 USC 242g, 243, 246, 247a note (1970).

Agency: U.S. Department of Health, Education and Welfare.

Purpose: To provide grants to help professional development.

Scope: This piece of legislation authorizes HEW to provide graduate public health trajning grants to schools of public health for professional training, technical assistance, consultative services. It includes a general grant of authority for Federal-state cooperation for enforcement to guarantee regulations and steps to prevention of communicable diseases; for comprehensive and continuing planning, training of personnel for state and local health work; and for problems resulting from disasters and emergencies. HEW may make grants to states for area-wide health planning (state plan required); grants for training, studies, and demonstrations to public or private nonprofit institutions; and grants for comprehensive health services (state plan 
required). The legislation also creates the Community Services Administration to replace $0 \mathrm{EO}$ and includes a mandate to continue PHS hospitals.

Title of Act: Partnership for Health Amendment of 1967, 42 USC 201 note, $217 \mathrm{~b}, 241,242 \mathrm{~b}, 242 \mathrm{c}$ note, $242 \mathrm{~g}, 243,244,246,249,251,254 \mathrm{a}, 263 \mathrm{a} 291 \mathrm{~m}-1$, 293 e, 295h-4, 296e note (1970).

Agency: U.S. Department of Health, Education and Welfare.

Purpose: To promote mental and physical health and help solve complex health care related problems.

Scope: This act contains authorization for Public Health Services; the use of volunteer services in operation of health care facilities; research and investigations relating to causes, diagnosis, treatment control and prevention of physical and mental diseases and impairments of man, including water purification, sewage treatment, and pollution of lakes and streams. These actions are promoted through fellowships, grants, and technical advice; grants and contracts for research and experiments and related training, and national health surveys and studies; the establishment of uniform systems of health information and statistics, and cooperation with other governmental agencies. In addition, HEW is mandated to call annual conferences of health authorities. The agency is also authorized to provide grants and services to states for comprehensive health palnning; medical care and treatment of seamen and certain other persons, medical examination of Federal employees--at remote stations; sharing of medical care facilities and service (PHS); 1 icensing of laboratories requirements and procedures; loans for certain hospital experimentation projects when other sources unavailable. Finally, under this amendment, HEW may make grants for construction of teaching facilities for medical, dental and other health personnel; for nurses training; and may authorize and fund grants for construction and institutional grants.

Title of Act: National Health Planning and Resources Act of 1974, 42 USC 300e-t (Supp. IV 1974).

Agency: U.S. Department of Health, Education and Welfare.

Purpose: To facilitate the development of recommendations for a national health planning policy, to augment area-wide and state planning for health services, manpower and facilities and to authorize financial assistance for the development of resources to further that policy.

Scope: HEW is mandated to develop national health planning policy guidelines--standards, priorities (e.g., primary care services including HMOs) and establishes the National Council of Health Planning and Development (advisory to the Secretary of HEW). This act establishes Health Service Areas--geographical regions throughout the country; and establishes health systems agencies which are nonprofit private, public regional planning body or local government. These HSAs are to do health planning--to develop plans to improve 
health, accessibility, the quality of health services, to restrain increased costs, prevent duplication of resources. The HSAs must produce a Health Systems Plan and Annual Implementation Plan. HEW may provide technical assistance in planning and developing plans, and approve use of certain Federal funds.

The act also requires the designation of state health planning agencies and state-wide health coordinating councils with state health planning functions. It also establishes a national health planning information center; and provides financial assistance for health planning centers. HEW reviews and approves annual budgets of state HSAs. $1974)$.

Title of Act: Health Resources Development Act, 42 USC 234 (Supp. IV

Agency: U.S. Department of Health, Education and Welfare.

Purpose: To provide assistance and loan guarantees and interest subsidies for new or modernized medical facilities.

Scope: The focus of assistance in this act is on medical facilities for areas with need (e.g., rural, urban poverty). It requires a State Medical Facilities Plan--approved by HEW. Annual allotments to states are based on population, financial need, and the need for medical facilities.

Loans and loan guarantees for facilities projects are made to nonprofit private entities and for public projects for construction or modernization of medical facilities.

Title of Act: Federal Aid Highway Act of 1973 and Amendments of 1974, 23 USC 101-324; 33 USC 526a; 49 USC 1602a (Supp. IV 1974).

Agency: Federal Highway Administration/U.S. Department of Transportation.

Purpose: To accelerate construction of the Federal aid highway systems, including the National System of Interstate and Defense Highways, and to make highways adequate to meet the needs of local and interstate commerce, and for the national and civil defense.

Scope: This act establishes four Federal aid systems--primary, urban, secondary, and interstate--designated by the states, and approved by the FHWA; it sets up an apportionment ratio for states, authorizes apportionments for advance acquisition of rights-of-way, it gives the Secretary authority to approve construction standards to meet needs for 20 years, and set standards for highway noise levels compatible with different land uses. Implementation projects are authorized; funds may be used for public toll roads, bridges, tunnels and ferries (part of the Interstate System). Funds for programs designed to reduce urban traffic congestion and to facilitate the flow of traffic in urban areas are authorized; as well as funds or exclusive transit lanes, and loading areas, etc. Funds for highways may be substituted for use 
on public transportation projects. The act also sets up the rural highway transportation demonstration program to encourage public transportation within rural areas and small urban areas. The act makes grants to states for various projects-- the construction and improvement of highways to serve and promote development of economic growth centers; to encourage the location of industry in rural areas; to facilitate mobility of labor in sparsely populated areas; to improve highways to public and private services.

The act also authorizes funds for the Alaska highway. Federal financial assistance is provided for mass transportation service and for the establishment of public transit corporations for entities. Loans to acquire rolling stock and real property are set up. Cooperation with states in long-range transportation plans is encouraged and projects which are funded must be part of two comprehensive plans.

The amendments are directed toward improving the rural primary road system with funds allocated on the basis of area, rural population and off-system road mileage. Legislative encouragement is given to special efforts for planning, design, construction and operation of mass transit facilities to make them more accessible to the elderly and handicapped.

Title of Act: National Mass Transportation Assistance Act of 1974, 42 USC 3303; 49 USC 1601b-1605 notes, 1611 (Supp. IV 1974).

Agency: U.S. Department of Transportation.

Purpose: To authorize the use of Federal funds for mass transit operating subsidies, and provide for increased mass transit assistance and expands the program authorizations from 2 to 6 years. It declares that it is in the national interest to promote the development of transportation systems embracing various modes of transportation to serve states and local communities effectively and efficiently.

Scope: The act requires that local fund recipients submit program proposals (governors along with local officials must develop long-range plans to improve and coordinate all forms of transportation within urbanized areas). A single Metropolitan Planning Organization (MPO) is to be designated by the governor for each urban area to direct the transportation planning effort and to perform functions of the planning process.

A comprehensive city demonstration program is eleigible for assistance only if the program includes a transportation component as a project or activity. Grants, loans--to develop plans, programs for transportation systems for urbanized areas--assistance for acquisition, construction, improvement of facilities (public transportation systems, real property); up to one half for operating expenses; bus purchase--restrictions (not used for school or charter service) are provisions of the act. Also authorized are: urban mass transit grant program--authorizes funds and apportions dollars among urbanized areas-$80 \%$ Federal share; cooperate in development of long-range plans and programs-requires elderly fares not to exceed one half fare during nonpeak hours, not 
required to charge fares to elderly or handicapped. Authorizes research, development and demonstration projects--in selected cities (those with failing system, air pollution problems or immobile central city population--encourages innovative service, multi-modal system; annual reports to President with findings and recommendations.

Title of Act: Intergovernmental Cooperation Act of 1968, 40 USC $531-535,42$ USC 4201-4211, 4214, 4221-4225, 4231, 4233, 4241-4244 (1970).

\section{Agency: Executive.}

\section{Purpose: To encourage intergovernmental cooperation.}

Scope: Until this act statutory requirements to coordinate the planning and design of direct Federal programs that have a significant state, local or regional influence were unevenly developed. Implementation regulations issued by the Bureau of the Budget under this act (A-95) call for the estab1 ishment of procedures by Federal agencies administering programs for construction of Federal building and installations on other Federal public works, or for the acquisition, use and disposal of Federal land and real property to assure:

1. Consultation with governors, regional and metropolitan comprehensive planning agencies, and local elected officials at the earliest practicable stage in project planning to determine the relationship of any project to the development plans and programs of the state, region or locality.

2. Consistency and compatibility of any such Federal project with state, regional and local development plans and programs.

The Bureau of the Budget regulations also call for use of the state, regional and metropolitan planning and development clearing houses that have been established as part of the recent efforts to improve intergovernmental coordination in planning, particularly for Federal grant-in-aid programs.

Title of Act: Joint Funding Simplification Act of 1974, 42 USC 4251-4261 (Supp. IV 1974).

Agency: Executive.

Purpose: To enable state and local governments to more effectively and efficiently utilize Federal assistance and to adapt Federal program assistance more readily to their particular needs.

Scope: The act provides the basis for 1) one comprehensive plan for receiving grants from several Federal agencies through one Federal funding source, 2) receiving Federal funds at times that coincide with the grantee's planning and funding cycles, 3) establishes uniform technical and administrative provisions (to resolve inconsistencies and conflict) in requirements, 
4) simplifies the paperwork and record keeping, 5) reports progress to one Federal agency and replaces separate Federal agency audits with a single audit by only one agency.

The burden for identifying programs suitable for integrated administration is shifted to Federal agencies. The act applies to a 11 Federal agencies in a consistent manner and heads of agencies are responsible for taking actions to further the purpose of the law. The act includes procedures for combining funds, the delegation of powers to further the purpose of the act, including the use of a single non-Federal share. 


\section{DISTRIBUTION}

No. of

Copies

\section{$\underline{\text { OFFSITE }}$}

A. A. Churm

ERDA Chicago Patent Group

9800 South Cass Avenue

Argonne, IL 60439

N. F. Barr

ERDA Division of Biomedical and Environmental Research

Washington, DC 20545

W. G. Belter

ERDA Division of Biomedical and Environmental Research

Washington, DC 20545

R. P. Blaunstein

ERDA Division of Biomedical and Environmental Research

Washington, DC 20545

H. D. Bruner

ERDA Division of Biomedical and Ervironmental Research Washington, DC 20545

W. W. Burr

ERDA Division of Biomedica? and Environmental Research

Washington, DC 20545

R. L. Butenhoff

ERDA Division of Biomedical and Environmental Research

Washington, DC 20545

D. W. Cole, Jr.

ERDA Division of Biomedical and Environmental Research Washington, DC 20545

J. Coleman

ERDA Division of Biomedical and Environmental Research

Washington, DC 20545

R. D. Cooper

ERDA Division of Biomedical and Environmental Research

Washington, DC 20545

C. W. Edington

ERDA Division of Biomedical and Environmental Research Washington, DC 20545

W. 0 . Forster

ERDA Division of Biomedical and Environmental Research Washington, DC 20545
No. of

Copies

P. Gearhardt

ERDA Division of Biomedical

and Environmenta] Research

Washington, DC 20545

J. S. Kirby-Smith

ERDA Division of Biomedical

and Environmental Research

Washington, DC 20545

J. L. Liverman

ERDA Division of Biomedical

and Environmental Research

Washington, DC 20545

J. E. Miller

ERDA Division of Biomedical

and Environmental Research

Washington, DC 20545

R. R. Newton

ERDA Division of Biomedical and Environmental Research

Washington, DC 20545

J. Swinebroad

ERDA Division of Biomedical and Environmental Research

Washington, DC 20545

H. R. Wasson

ERDA Division of Biomedica? and Environmental Research

Washington, DC 20545

W. H. Weyzen

ERDA Division of Biomedical and Environmental Research Washington, DC 20545

R. W. Wood

ERDA Division of Biomedical and Environmental Research Washington, DC 20545

H. L. Hollister

ERDA Division of Environmental Control Technology

Washington, DC 20545

W. E. Mott

ERDA Division of Environmental Control Technology

Washington, DC 90545

M. Reilly

ERDA Division of Fossil Energy

Washington, DC 20545

A. B. Joseph

Office of Nuclear Regulatory Research

U.S. Nuclear Regulatory Commission

Washington, DC 20555
No. of

Copies

F. G. Lowman

Office of Nuclear Regulatory Research

U.S. Nuclear Regulatory

Commission

Washington, DC 20555

E. E. Held

Office of Standards Development

U.S. Nuclear Regulatory Commission

Washington, DC 20555

ERDA Technical Information Center

J. B. Roberts

Federal Energy Administration Room 1992

Federal Building

915 Second Avenue

Seattle, WA 98174

L. E. Coate

U.S. Environmental Protection Agency, Region $X$

Seattle, WA 98101

L. J. Hoover

Argonne National Laboratory 9700 South Cass Avenue

Argonne, IL 60439

R. Meier

Brookhaven National Laboratory Upton, NY 11973

P. Palmedo

Brookhaven National Laboratory Upton, NY 11973

W. Siri

University of California - LBL Lawrence Berkeley Laboratory Berkeley, CA 94720

R. Ritschard University of California - LLL Lawrence Livermore Laboratory P. O. Box 808

Livermore, CA 94550

R. Malenfant

Los Alamos Scientific Laboratory University of $\mathrm{Cal}$ ifornia

P.0. Box 1663

Los Alamos, NM 87545

S. J. Auerbach

Oak Ridge National Laboratory

P.0. Box $X$

Oak Ridge TN 37830 
No. of

Copies

W. Fulkerson

Oak Ridge National Laboratory

P.0. Box $X$

Oak Ridge, TN 37830

Col. Charles A. Debelius

District Engineer

Alaska District

Corps of Engineers

Anchorage, AK 99510

\section{R. Estess}

State Clearinghouse

Division of Policy Development and Planning

Office of the Governor

Pouch $A D$

Juneau, AK 99801

J. Lowell Jensen

Public Utilities Conmission

1100 Mackay Building

338 Denali Street

Anchorage, AK 9950 ]

W. C. McConkey

Alaska State Energy Office

Mackay Building

338 Denali Street

Anchorage, AK 99501

G. Martin

Department of Natural Resources

11 th Floor, State Office Bldg.

Pouch M

Juneau, AK 99811

\section{F. Thomas}

Regional Engineer

Bureau of Power

555 Battery Street, Room 415

San Francisco, CA 94111

D. Guss

Bureau of State Planning and Community Affairs

State House

Boise, ID 83720

\section{Montgomery}

Idaho Office of Energy

300 North 6th Street

Boise, ID 83720

K. D. Smith

Public Utilities Commission

$472 \mathrm{~W}$. Washington Street

Boise, ID 83720

R. J. Vissia

Regional Director

Pacific Northwest Region

(Columbia River Basin)

Federal Building,

U.S. Court House

$550 \mathrm{~W}$. Fort Street

Boise, ID 83724

No. of

Copies

R. N. Wise

Bureau of State Planning and Community Affairs

State House

Boise, ID 83720

R. Hulme

State Clearinghouse

Office of Budget and Program Planning

232 Capitol Building

Helena, MT 59601

M. O. Mortensen

Energy Advisory Council

c/O Lt. Governor's Office

Capitol Building

Helena, MT 59601

J. Nybo

Energy Advisory Council

c/o Lt. Governor's Office

Capitol Building

Helena, MT 59601

W. Opitz

Publ ic Service Commission

122711 th Avenue

Helena, MT 59601

B. Roberts

State Land Use Planning Bureau Department of Conmunity Affairs Capitol Post Office

Helena, MT 59601

A. C. Tsao

Energy Planning Division

Department of Natural Resources and Conservation

32 South Ewing

Helena, MT 59601

H. Brauner

Conservation and Development

Commission

1175 Court Street N.E.

Salem, OR 97301

Charles Davis

Public Utility Commissioner

Labor and Industries Bldg.

Salem, OR 97310

Col. C. D. Gilkey

District Engineer

Portland District

Corps of Engineers

2850 S.E. 82 nd Ave. (97266)

P.0. Box 2946

Portland, OR 97208
No. of

Copies

Maj. Gen. H. E. Peel

Division Engineer

North Pacific Division

Corps of Engineers

210 Custom House

Portland, OR 97209

L. Topaz

Oregon Department of Energy

528 Cottage, N.E.

Salem, OR 97310

Dr. K. Woods

Energy Facility Siting Division

Department of Energy

528 Cottage, N.E.

Salem, OR 97310

W. Young

Intergovernmental Relations Division

Office of the Governor

240 Cottage Street, S.E.

Salem, OR 97310

F. S. Adair

Washington State Department of Commerce and Economic Development

01ympia, WA 98504

Col. N. P. Conover

District Engineer

Walla Walla District

Corps of Engineers

Bldg. 602, City-County Airport

walla Walla, WA 99362

Col. Raymond J. Eineigl

District Engineer

Seattle District

Corps of Engineers

1519 Alaskan Way South

Seattle, WA 98134

N. Lewis

Assistant Director

Office of Program Planning and Fiscal Management

State Planning Division

House Office Building

01 ympia, WA 98504

R. Polson

Energy Facilities Site

Evaluation Council

820 East Fifth Avenue

Olympia, WA 98504

E. T. Shaw

Utilities and Transportation Commission

Highways-Licenses Building

01 ympia, WA 98504 
No. of

Copies

K. Sherman

Washington State Energy Office

1000 Cherry

Olympia, WA 98504

M. Walsh

Department of Ecology

State of Washington

Olympia, WA 98504

A. J. Eliopulos

Public Service Commission

Supreme Court Building

Cheyenne, WY 82002

D. B. Freudenthal

State Planning Coordinator's Office

Office of the Governor

State Capitol

Cheyenne, WY 82002

D. Hoffman

Mineral Development Division

Department of Economic Planning and Development

720 West 18th Street

Cheyenne, WY 82002

F. C. Blood

Bonneville Power Administration P.0. Box 3621

Portland, OR 97208

R. S. Gens

Bonneville Power Administration

P.O. Box 3621

Portland, OR 97208

3. Hoozen

Bonneville Power Administration

P.O. Box 3621

Portland, OR 97208

J. C. Loosli

Bonneville Power Administration

P.0. Box 3621

Portland, OR 97208

C. M. Moore

Bonneville Power Administration

P.0. Box 3621

Portland, OR 97208

M. Katz

Northwest Energy Policy Project

1096 Lloyd Building

700 N.E. Multnomah Street

Portland, OR 97232

R. Lewis

Northwest Energy Policy Project

1096 Lloyd Building

700 N.E. Multnomah Street

Portland, OR 97232
No. of

Copies

W. E. Bruner

Pacific Northwest Regional

Commission

1205 Washington

Vancouver, WA 98660

D. J. Lane

Pacific Northwest River Basins Commission

1 Columbia River

P.0. Box 908

Vancouver, WA 98660

Dr. 0. Osborne

Oregon State University

Electrical Engineering

Department

Corvallis, OR 97331

Dr. R. Wensink

Oregon State University

Agricultural Engineering Department

Corvalits, OR 97331

Dr. J. Jaksch

Corvall is Environmental Research Laboratory

Corvallis Environmental

Protection Agency

Corvallis, OR 97331

3. Brar

Washington State University

Pullman, WA 99163

G. Hinman

Washington State University

Pullman, WA 99163

R. T. Miller

Vice President

Engineering and Gas Control

Northwest Natural Gas Company

123 N.W. Flanders Street

Portland, OR 97209

H. S, Johnson

Portland General Electric Co. 621 S.W. Alder Street

Portland, OR 97205

G. A. Perrault

Portland General Electric Co.

621 S.W. Alder Street

Portland, OR 97205

C. L. Sauvie

Portland General Electric Co.

621 5.W. Alder Street

Portland, OR 97205
No. of

Copies

J. L. Williams

Portland General Electric Co. 621 S.W. Alder Street

Portland, OR 97205

R. A. Duncan

Coordination Engineer

Northwest Power Pool

920 S.W. 6th Ave., Rm. 1210

Portland, OR 97204

H. Kosmata

Washington Public Power Supply System

3000 George Washington Way

Richland, WA 99352

D. Renberger

Washington Public Power Supply System

3000 George Washington Way

Richland, WA 99352

R. Tillson

Washington Public Power Supply System

3000 George Washington Way

Richland, WA 99352

R. Woodruff

Washington Public Power Supply System

3000 George Washington Way

Richland, WA 99352

D. N. Morris

The Rand Corporation

1700 Main Street

Santa Monica, CA 90406

J. W. Ellis

Puget Sound Power and Light Company

Puget Power Building

Bellevue, WA 98009

L. E. Hall

Puget Sound Power and Light Company

Puget Power Building

Bellevue, WA 98009

B. C. Thomas

Puget Sound Power and Light Company

Puget Power Building

BeIlevue, WA 98009

T. E. Browne

Electric Power Research Institute

$3412 \mathrm{Hillview} \mathrm{Avenue}$

P.0. Box 10412

Palo Alto, CA 94304 
No. of

Copies

R. Crow

Electric Power Research Institute

3412 Hillview Avenue

P.0. Box 10412

Palo Alto, CA 94304

M. Greenburger

Electric Power Research Institute

3412 Hillview Avenue

P.0. Box 10412

Palo Alto, CA 94304

L. Henning

Electric Power Research Institute

$3412 \mathrm{Hillview} \mathrm{Avenue}$

P.0. Box 10412

Palo Alto, CA 94304

H. A. Kornburg

Electric Power Research Institute

$3412 \mathrm{Hillview}$ Avenue

P.0. Box 10412

Palo Alto, CA 94304

M. Searle

Electric Power Research institute

$3412 \mathrm{Hillview}$ Avenue

P.0. Box 10412

Palo Alto, CA 94304

S. Boris

Teknekron Corp.

2118 Miluia Street

Bereley, CA 94704

J. W. LaFond

City of Seattie

Department of Lighting

1015 Third Avenue

Seattie, WA 98104

R. Sheehan

City of Seattle

Department of Lighting

1015 Third Avenue

Seattle, WA 98104

J. McFadden

Energy Ave.

Box 736

Idaho Falls, ID 83401

K. Blackburn

0id West Regional Commission

Fratt Building, Suite 306A

Billings, MT 59101
No. of

Copies

G. Culp

Culp, Dwyer, Guterson, and Grader

Hoge Building

Second and Cherry

Seattle, WA 98104

B. Goldhammer

Loyde Building

700 NE Mul tnomah

Portland, OR 97232

H. C. Elmore

Pacific Northwest Utilities Conference Committee

P. 0 . Box 1231

Wenatchee, WA 98801

D. J. Lewis

Public Service Building

920 S.W. Sixth

Portland, OR 97204

R. A. Hofacker

Montana Power Company

40 East Broadway

Butte, MT 59701

R. H. Bendio

Idaho Power Company

P.0. Box 70

Boise, ID 83721

H. W. Harding

Washington Water Power Company

P.0. Box 3727

Spokane, WA 99220

H. G. Curtis

Public Power Council

P.0. Box 1307

Vancouver, WA 98660

Scott Alstrom

Western States Water Council

220 South Second East, Suite 200

Salt Lake City, UT 84111

J. T. Stiles

Pacific Power and Light

Portland, OR 97204

W. Rogers, Jr.

Western Interstate Nuclear Board

P.0. Box 15038

Lakewood, CO 80215

L. Harris

Western Aluminum Producers

P.0. Box 8484

Portland, OR 97207
No. of

Copies

W. L. Guy

Western Governors' Regional

Energy Policy Office

4730 Oakland St.

Denver, CO 80239

K. Muller

Northern Plains Resource Council

418 Stapleton Building

Billings, MT 59101

J. Binanado

Regional Planner

Bureau of Land Management

P. O. Box 30157

Billings, MT 59107

W. Tomlinson

Environmental Library

Rm 208A Natural Sciences

University of Montana

Missoula, MT 5980

R. Doel1

U.S. Geological Survey

354 Middlefield Road

Menlo Park, CA 94025

Battelle-Northwest

Human Affairs Research Center (HARC)

M. G. Curry

M. Green

J. A. Hebert

M. Mertaugh

D. J. Merwin

M. E. Olsen

D. A. Summers

$\mathrm{R}$. Schuller

ONSITE

ERDA Richland Operations office

P. W. Gottschalk

G. L. Liffick

R. H. Lindsey

B. J. Melton

51 Battelle-Northwest

F. W. Albaugh

W. J. Bair

C. H. Bloomster

J. B. Burnham

D. B. Cearlock

L. L. Clark

M. Clement

B. W. Cone

J. W. Currie

D. E. Deonigi 
No. of

Copies

Battelle-Northwest - (Continued)

P. J. Dionne

D. W. Dragnich

D. L. Elliot

L. E. Erickson

D. W. Fraley

T. J. Foley

J. C. Fox

T. P. Harrington

P. L. Hendrickson

E. R. Hill

J. J. Jacobsen

J. King

C. A. Knutsen

T. P. Kula

J. W. Litchfield

K. A. McGinnis

S. Marks

W. A. Reardon

D. S. Renne

W. H. Rickard

R. H. Sauer

L. C. Schmid

S. J. Shupe

W. H. Swift (10)

W. L. Templeton

D. W. Uresk

B. E. Vaughan

R. D. Widrig

G. L. Wilfert

K. E. Yandon

J. R. Young

20 Economics Library

3 Technical Information files

Technical Publications 